\title{
Elemental composition and clustering behaviour of $\alpha$-pinene oxidation products for different oxidation conditions
}

\author{
A. P. Praplan ${ }^{1}$, S. Schobesberger ${ }^{1, *}$, F. Bianchi ${ }^{2,3}$, M. P. Rissanen ${ }^{1}$, M. Ehn ${ }^{1}$, T. Jokinen ${ }^{1}$, H. Junninen ${ }^{1}$, A. Adamov ${ }^{1}$, \\ A. Amorim ${ }^{4}$, J. Dommen ${ }^{2}$, J. Duplissy ${ }^{5}$, J. Hakala ${ }^{1}$, A. Hansel ${ }^{6,7}$, M. Heinritzi ${ }^{8,6}$, J. Kangasluoma ${ }^{1}$, J. Kirkby ${ }^{9,8}$, \\ M. Krapf ${ }^{2}$, A. Kürten ${ }^{8}$, K. Lehtipalo ${ }^{1}$, F. Riccobono ${ }^{2}$, L. Rondo ${ }^{8}$, N. Sarnela ${ }^{1}$, M. Simon ${ }^{8}$, A. Tomé ${ }^{4}$, J. Tröstl $^{2}$, \\ P. M. Winkler ${ }^{10}$, C. Williamson ${ }^{8}$, P. Ye ${ }^{11}$, J. Curtius ${ }^{8}$, U. Baltensperger ${ }^{2}$, N. M. Donahue ${ }^{11}$, M. Kulmala ${ }^{1,5}$, and \\ D. R. Worsnop ${ }^{1,12}$ \\ ${ }^{1}$ Department of Physics, P.O. Box 64, 00014 University of Helsinki, Helsinki, Finland \\ ${ }^{2}$ Laboratory of Atmospheric Chemistry, Paul Scherrer Institute, 5232 Villigen PSI, Switzerland \\ ${ }^{3}$ Institute for Atmospheric and Climate Science, ETH Zurich, 8092 Zurich, Switzerland \\ ${ }^{4}$ Laboratory for Systems, Instrumentation, and Modeling in Science and Technology for Space and the Environment (SIM), \\ University of Lisbon and University of Beira Interior, 1749-016 Lisbon, Portugal \\ ${ }^{5}$ Helsinki Institute of Physics, University of Helsinki, Helsinki, Finland \\ ${ }^{6}$ University of Innsbruck, Institute for Ion Physics and Applied Physics, Technikerstrasse 25, 6020 Innsbruck, Austria \\ ${ }^{7}$ Ionicon Analytik, Eduard Bodem Gasse 3, 6020 Innsbruck, Austria \\ ${ }^{8}$ Institute for Atmospheric and Environmental Sciences, Goethe University Frankfurt am Main, Altenhöferallee 1, 60438 \\ Frankfurt am Main, Germany \\ ${ }^{9}$ CERN, CH1211, Geneva, Switzerland \\ ${ }^{10}$ Faculty of Physics, University of Vienna, Boltzmanngasse 5, 1090 Vienna, Austria \\ ${ }^{11}$ Center for Atmospheric Particle Studies, Carnegie Mellon University, 5000 Frobes Ave, Pittsburgh, PA 15213, USA \\ ${ }^{12}$ Aerodyne Research Incorporated, Billerica, MA 01821, USA \\ * now at: University of Washington, Department of Atmospheric Sciences, Box 351640, Seattle, WA 98195, USA
}

Correspondence to: A. P. Praplan (arnaud.praplan@gmail.com)

Received: 7 November 2014 - Published in Atmos. Chem. Phys. Discuss.: 9 December 2014

Revised: 16 March 2015 - Accepted: 17 March 2015 - Published: 22 April 2015

\begin{abstract}
This study presents the difference between oxidised organic compounds formed by $\alpha$-pinene oxidation under various conditions in the CLOUD environmental chamber: (1) pure ozonolysis (in the presence of hydrogen as hydroxyl radical $(\mathrm{OH})$ scavenger) and (2) $\mathrm{OH}$ oxidation (initiated by nitrous acid (HONO) photolysis by ultraviolet light) in the absence of ozone.

We discuss results from three Atmospheric Pressure interface Time-of-Flight (APi-TOF) mass spectrometers measuring simultaneously the composition of naturally charged as well as neutral species (via chemical ionisation with nitrate). Natural chemical ionisation takes place in the CLOUD chamber and organic oxidised compounds form clusters with nitrate, bisulfate, bisulfate/sulfuric acid clusters, ammonium, and dimethylaminium, or get protonated. The results from this study show that this process is selective for various oxi-
\end{abstract}

dised organic compounds with low molar mass and ions, so that in order to obtain a comprehensive picture of the elemental composition of oxidation products and their clustering behaviour, several instruments must be used. We compare oxidation products containing 10 and 20 carbon atoms and show that highly oxidised organic compounds are formed in the early stages of the oxidation.

\section{Introduction}

Oxidation of organic vapours in the atmosphere and the subsequent condensation of their products is a source of secondary organic aerosol (SOA, see e.g. Kanakidou et al., 2005; Fuzzi et al., 2006; Hallquist et al., 2009, and references therein). Because of the vast number of different compounds 
in the atmosphere, with various structures and functionalities, detailed oxidation mechanisms are usually insufficiently understood and poorly represented in atmospheric chemical models, especially for larger and complex molecules (Goldstein and Galbally, 2007; Kroll and Seinfeld, 2008). Traditionally, oxidised organic compounds have been considered condensing on small pre-existing particles (few nanometres in diameter) to make them grow up to cloud condensation nuclei sizes (larger than 50 to $100 \mathrm{~nm}$ diameter). In general, the more oxidised these products, the lower is their volatility; therefore, they can condense on smaller particles, contributing to SOA (Pankow, 1994; Seinfeld and Pankow, 2003; Donahue et al., 2006, 2011). However, new studies have shown that $\alpha$-pinene oxidation products (and oxidised organic compounds in general) not only participate in particle growth but also directly influence particle formation (Riccobono et al., 2012; Kulmala et al., 2013). It has been shown that sulfuric acid forms clusters, which are stabilised by oxidised organic compounds participating directly in the nucleation process (Metzger et al., 2010; Riccobono et al., 2014). Other compounds such as ammonia (Kirkby et al., 2011; Schobesberger et al., 2015) or amines (Almeida et al., 2013; Kürten et al., 2014) can promote sulfuric acid nucleation as well due to an efficient acid-base stabilisation mechanism.

Monoterpenes $\left(\mathrm{C}_{10} \mathrm{H}_{16}\right)$ are a family of biogenic volatile organic compounds. In boreal forests, $\alpha$-pinene is the most abundant monoterpene. It has been extensively studied in laboratory experiments during the past decades due to its large SOA formation potential (Hoppel et al., 2001; Lee and Kamens, 2005; Eddingsaas et al., 2012a). Several oxidation pathways are known (see Fig. 1).

- One pathway is ozonolysis, in which ozone $\left(\mathrm{O}_{3}\right)$ reacts with the $\alpha$-pinene double bond, forming a primary ozonide, which will decompose in Criegee intermediates (Ma et al., 2008; Novelli et al., 2014). These can form carboxylic acids (via rearrangement of dioxiranes) or vinylhydroperoxides, which, upon hydroxyl radical $(\mathrm{OH})$ elimination, lead to carbonyl compounds.

- Another pathway is $\mathrm{OH}$ or nitrate radical $\left(\mathrm{NO}_{3}\right)$ oxidation, in which the radical adds to the $\alpha$-pinene double bond (or, alternatively, abstracts a hydrogen atom from $\alpha$-pinene in the case of $\mathrm{OH}$ ) resulting in the formation of an alkyl radical. Under atmospheric conditions this radical reacts immediately with molecular oxygen $\left(\mathrm{O}_{2}\right)$ forming a peroxy radical $\left(\mathrm{RO}_{2}\right)$. This peroxy radical can react with various species including other peroxy radicals.

Figure 1 is discussed more extensively in Sect. 3.3. Both gas phase and particulate $\alpha$-pinene oxidation products have been investigated, and more detailed chemical analyses have become available as analytical methods have progressed recently (Hatakeyama et al., 1989; Kamens et al., 1999; Claeys et al., 2009; Eddingsaas et al., 2012a, b; Winkler et al., 2012). Products such as the dicarboxylic acid cis-pinic acid $\left(\mathrm{C}_{9} \mathrm{H}_{14} \mathrm{O}_{4}\right.$, Christoffersen et al., 1998), the tricarboxylic acid 3-methyl-1,2,3butanetricarboxylic acid (MBTCA, $\mathrm{C}_{8} \mathrm{H}_{12} \mathrm{O}_{6}$, Szmigielski et al., 2007) and oligomeric compounds (Tolocka et al., 2004; Müller et al., 2009) have been identified. Ehn et al. (2012, 2014) and Schobesberger et al. (2013) have recently observed highly oxidised multifunctional organic compounds (i.e. extremely low volatility organic compounds (ELVOCs), already predicted by Kulmala et al., 1998) based on laboratory experiments and ambient measurements in Hyytiälä, Finland, with oxygen-to-carbon ratios $(\mathrm{O}: \mathrm{C})$ exceeding 1. As an alternative to $\mathrm{O}: \mathrm{C}$, Kroll et al. (2011) suggested the average oxidation state of carbon $\overline{\mathrm{OS}}_{\mathrm{C}}$ as a metric for the degree of oxidation of atmospheric organic compounds. It can be estimated by $\overline{\mathrm{OS}}_{\mathrm{C}} \approx 2(\mathrm{O}: \mathrm{C})-\mathrm{H}: \mathrm{C}$.

As the formation of newly observed compounds from field studies or from laboratory experiments could not be explained with "traditional" atmospheric chemistry (Atkinson, 2000), new suggestions for mechanisms have been published. Intramolecular reactions seem to play an especially important role in the formation of highly oxidised compounds (Peeters et al., 2001; Vereecken and Peeters, 2004; Ma et al., 2008; Ehn et al., 2014). However, current atmospheric chemical models include only few such nontraditional oxidation mechanisms (e.g. intramolecular reactions).

Building on this knowledge, experiments have been conducted within the CLOUD project at CERN to investigate the formation of new particles from organic vapours under various oxidation regimes (ozone and hydroxyl radical oxidation). The CLOUD chamber (described in more detail in the next section) has extremely low background contamination levels, and therefore provides excellent conditions for unperturbed nucleation experiments (Schnitzhofer et al., 2014). Additionally, CLOUD makes use of CERN's Proton Synchrotron (PS) facility in order to simulate various galactic cosmic ray (GCR) intensities (increased ion pair concentration).

The results presented in this paper focus on the underlying chemistry of $\alpha$-pinene oxidation, based on mass spectrometry measurements. The study investigates positive, negative and neutral species observed in the CLOUD chamber during $\alpha$-pinene oxidation at a given relative humidity and temperature. Two different oxidation pathways have been investigated: ozonolysis in the presence of an $\mathrm{OH}$ scavenger and $\mathrm{OH}$ oxidation with only background levels of ozone. We first present the general differences between both systems before focussing on a subset of oxidised organic compounds, to show how the elemental composition of oxidation products varies. The interactions of these various compounds with inorganic ions and clusters are discussed, and their temporal evolution is presented in order to investigate formation mechanisms. 


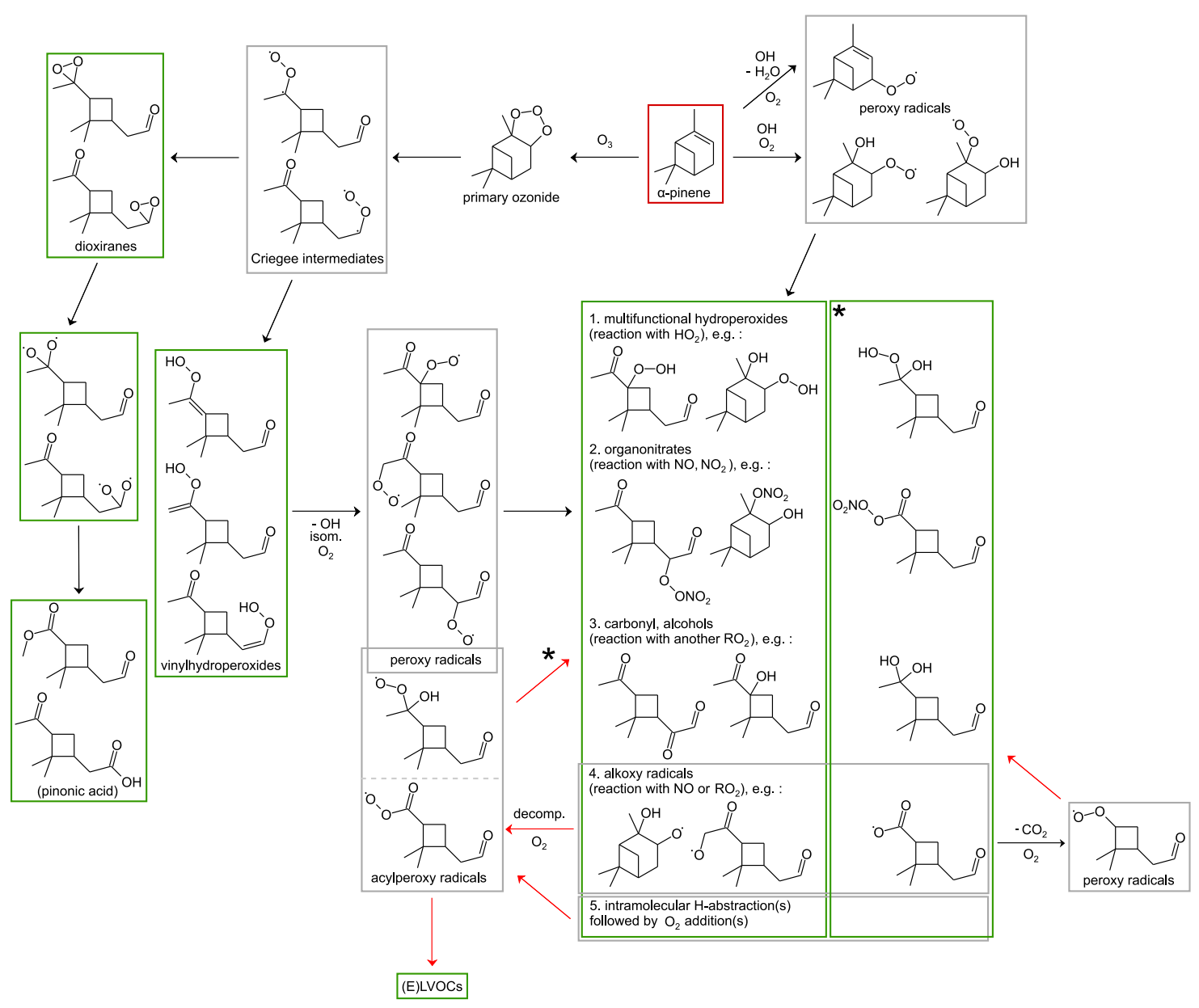

Figure 1. Non-exhaustive summary of $\alpha$-pinene ozonolysis (left) and $\mathrm{OH}$ oxidation (right) reaction pathways. Oxidation by $\mathrm{NO}_{3}$ has been left out for the sake of clarity and because it is not relevant to the present study. Not all possible reaction pathways and final products are displayed but only representative examples. Products (either stable or intermediates) have been grouped in boxes to indicate that several products may arise from the same reaction. The green box marked with a star $(*)$ corresponds to products formed from (acyl)peroxy radicals (red arrow marked with a star). See main text and discussion for details.

\section{Experimental}

The CLOUD (Cosmics Leaving Outdoor Droplets) facility is located at CERN (Meyrin, Switzerland) and consists of a $26.1 \mathrm{~m}^{3}$ stainless steel reactor in a temperature-controlled enclosure. The facility is described in more detail by Kirkby et al. (2011). Thorough cleaning with ultra-pure water and heat $(373 \mathrm{~K})$ decreases contaminant levels such as ammonia and amines to a few pptv, and volatile organic compounds to below 1 ppbv (Praplan et al., 2012; Schnitzhofer et al., 2014). However, only heating and flushing with the ultra-pure air of the chamber has been performed between experiments with ammonia and dimethyl amine and the experiments presented in this paper, which is somewhat less efficient than the use of water.

The chamber is used as a continuously stirred reactor. It is constantly flushed with ultra-pure air produced from cryogenic molecular nitrogen $\left(\mathrm{N}_{2}\right)$ and $\mathrm{O}_{2}$ in a $79: 21$ ratio. Trace gases, such as water, sulfur dioxide $\left(\mathrm{SO}_{2}\right), \mathrm{O}_{3}$, and $\alpha$-pinene are carefully injected to desired levels and monitored. Time resolutions vary from seconds to minutes. An optical fibre ultraviolet (UV) irradiation setup (Kupc et al., 2011) produces hydroxyl radicals from nitrous acid (HONO) photolysis for the OH oxidation experiments (Cox, 1974). HONO is generated continuously from sodium nitrite and sulfuric acid solutions according to the method described in Taira and Kanda (1990). An additional strong UV source - a Philips TUV 130W XPT lamp producing 50W power, essentially monochromatic at $253.7 \mathrm{~nm}$, and installed in a quartz tube inserted into the chamber (called "UV sabre") - is used to increase $\mathrm{OH}$ levels in the $\mathrm{OH}$ experiment presented in this paper. The use of a pion beam $\left(\pi^{+}\right)$from CERN's Proton Synchrotron increases the concentration of ions present in the chamber up to ca. 4000 ion pairs $\mathrm{cm}^{-3}$ for the experiments presented in this study. 
Table 1. Conditions of selected runs. The given values correspond to the period with constant $\left[\mathrm{H}_{2} \mathrm{SO}_{4}\right]$.

\begin{tabular}{lccccccc}
\hline Run & $\begin{array}{c}\alpha \text {-pinene } \\
(\mathrm{pptv})\end{array}$ & $\begin{array}{c}\mathrm{O}_{3} \\
(\mathrm{ppbv})\end{array}$ & $\begin{array}{c}\mathrm{SO}_{2} \\
(\mathrm{ppbv})\end{array}$ & $\begin{array}{c}\mathrm{HONO} \\
(\mathrm{ppbv})\end{array}$ & $\begin{array}{c}\mathrm{H}_{2} \\
(\%)\end{array}$ & $\begin{array}{c}\mathrm{UV} \\
{\left[\mathrm{H}_{2} \mathrm{SO}_{4}\right]} \\
\mathrm{cm}^{-3}\end{array}$ \\
\hline 1070.02 & 660 & 22 & 69 & 0 & 0.1 & no & $1.91 \times 10^{7}$ \\
1100.02 & 1250 & 0.8 & 1.1 & $2.1 \pm 0.2$ & 0 & yes & $1.03 \times 10^{7}$ \\
\hline
\end{tabular}

The CLOUD7 campaign was conducted between September and December 2012. Table 1 summarises the conditions of representative experiments for ozonolysis and $\mathrm{OH}$ oxidation used in this analysis. For the ozonolysis experiment, ozone was set to about $22 \mathrm{ppbv}$ and the oxidation was triggered by the injection of $\alpha$-pinene. Hydrogen $\left(\mathrm{H}_{2}\right)$ was used as an $\mathrm{OH}$ scavenger $(0.1 \%)$. For the $\mathrm{OH}$ oxidation experiment $\mathrm{HONO}$ and $\alpha$-pinene were introduced until they reached stable concentrations (about $1.9 \pm 0.7 \mathrm{ppbv}$ and $1250 \mathrm{pptv}$, respectively). In this case, the oxidation was triggered by turning on the UV lights. A model estimation based on the Master Chemical Mechanism (v3.2) and parametrisation of the UV sabre estimated the $\mathrm{OH}$ concentration to vary between 8 and $9.3 \times 10^{5} \mathrm{~cm}^{-3}$. In both experiments, sulfuric acid $\left(\mathrm{H}_{2} \mathrm{SO}_{4}\right)$ is formed by oxidation of $\mathrm{SO}_{2}$. Despite the cleanliness of the chamber, ammonia $\left(\mathrm{NH}_{3}\right)$ and dimethylamine $\left(\mathrm{C}_{2} \mathrm{H}_{7} \mathrm{~N}\right)$ are present as trace contaminants.

State-of-the-art particle counters and sizers were deployed, as well as recently developed mass spectrometers. The instrumentation is described in detail in Almeida et al. (2013). We present in this paper results from three highresolution mass spectrometers:

- an Atmospheric Pressure interface Time-of-Flight (APiTOF) mass spectrometer in positive mode

- an APi-TOF mass spectrometer in negative mode (Junninen et al., 2010)

- and a chemical ionisation APi-TOF (CI-APi-TOF) using nitrate $\left(\mathrm{NO}_{3}^{-}\right)$as ionising reagent (Jokinen et al., 2012).

Both APi-TOF mass spectrometers measure ions and charged molecular clusters as present in the chamber, whereas the CIAPi-TOF measures neutral molecules and clusters charged by $\mathrm{NO}_{3}^{-}$(either by proton transfer or by forming an adduct). High-resolution spectra acquired with these instruments were analysed using the tofTools data analysis software (Junninen et al., 2010).

\section{Results and discussion}

\subsection{Mass defect plots}

Mass defect plots are a convenient way to visualise highresolution mass spectral data (Kendrick, 1963; Sleno, 2012).
The difference between the exact mass and the integer (nominal) mass of a detected compound (i.e. its mass defect) is plotted against its exact mass. Figure 2 presents the mass defect plots from three different instruments (positive and negative APi-TOFs, as well as nitrate CI-APi-TOF) for the two different oxidation conditions. The mass spectra have been averaged over the time periods when sulfuric acid reached a stable concentration.

All plots show a similar structure, as the signals tend to be organised in "bands", resembling clouds of markers oriented diagonally (from upper left to lower right). The bands are most pronounced in mass defect plots for anions (b and e). The first band is located on the left with lower mass defect values and the following bands are located more to the right and higher on the mass defect axis. The size of the markers is proportional to the natural logarithm of the peak area in the mass spectra ( $>0.01 \mathrm{~s}^{-1}$ in this study) and they have been coloured according to the retrieved elemental composition (grey points have unidentified composition). The organic compounds in the first band are predominantly species with 10 carbon atoms (" $\mathrm{C}_{10}$ "), while in the second band they are mainly compounds with 20 carbon atoms (" $\mathrm{C}_{20}$ "), but also compounds with a different number of carbon atoms are detected ("C $\mathrm{C}_{8} "$, " $\mathrm{C}_{9} "$, " $\mathrm{C}_{19}$ ", etc.).

Attributing unambiguous elemental composition based solely on the negative spectra is challenging, as $\mathrm{O}_{6}$ and $\mathrm{SO}_{4}$ have nearly identical masses $(95.969$ and $95.952 \mathrm{u}$, respectively). Higher mass resolution would be required to distinguish between them. Nevertheless, based on previous studies (Ehn et al., 2010, 2012; Junninen et al., 2010; Jokinen et al., 2012; Schobesberger et al., 2013), isotopic patterns, and assumptions on chemical reactions and clustering behaviour, the elemental composition of most compounds could be retrieved. For instance we assume that no organonitrate compound would form in the ozonolysis-only experiment. For signals with low intensity, the elemental composition could sometimes be inferred by extending a pattern (e.g. increasing or decreasing the number of oxygen atoms or adding sulfuric acid molecules to $\left.\left(\mathrm{C}_{10} \mathrm{H}_{\mathrm{b}} \mathrm{O}_{\mathrm{c}}\right) \mathrm{HSO}_{4}^{-}\right)$. In the present study, the comparison with positive and neutral spectra has been the key for the unambiguous attribution of elemental composition (see Sect. 3.3). The composition $\left(\mathrm{C}_{20} \mathrm{H}_{30} \mathrm{O}_{12}\right) \mathrm{HSO}_{4}^{-}$ was for example selected over $\left(\mathrm{C}_{20} \mathrm{H}_{28} \mathrm{O}_{6}\right)\left(\mathrm{H}_{2} \mathrm{SO}_{4}\right) \mathrm{HSO}_{4}^{-}$ as no $\mathrm{C}_{20} \mathrm{H}_{28} \mathrm{O}_{6}$ compound was measured with the other instruments.

In the mass defect plots from negative ( $b$ and e) and neutral ( $\mathrm{c}$ and $\mathrm{f}$ ) species the red markers represent the clusters containing only sulfuric acid molecules $\left(\left(\mathrm{H}_{2} \mathrm{SO}_{4}\right)_{n} \mathrm{HSO}_{4}^{-}\right.$ $(n=1,2))$ and blue points represent nitric acid clusters $\left(\left(\mathrm{HNO}_{3}\right)_{n} \mathrm{NO}_{3}^{-}(n=1,2)\right)$. Ammonia-sulfuric acid clusters are present in the negative spectra. They are the points marked in pink with mass-to-charge ratio larger than $400 \mathrm{Th}$ and mass defect smaller than -0.1 (Bianchi et al., 2014). Some compounds are deprotonated (dark green) and, because 

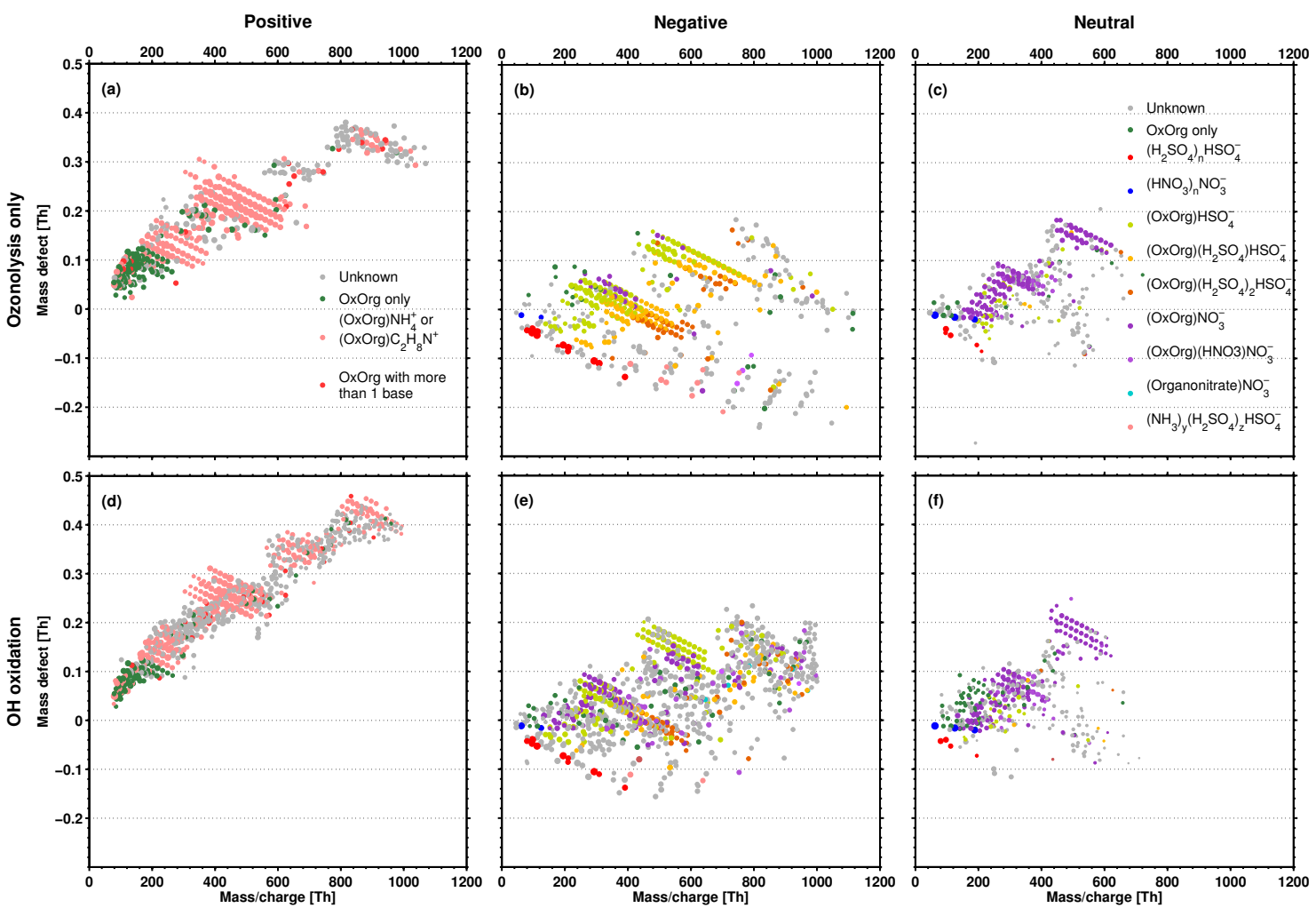

Figure 2. Mass defect plots derived from detected cations (positive APi-TOF, a and d), anions (negative APi-TOF, b and e), and neutral molecular clusters (CI-APi-TOF, $\mathbf{c}$ and $\mathbf{f}$ ) of $\alpha$-pinene ozonolysis with $\mathrm{OH}$ scavenger $(\mathbf{a}-\mathbf{c})$ and $\alpha$-pinene oxidation by $\mathrm{OH}$ only $(\mathbf{d}-\mathbf{f})$. The legend in (a) applies to panel (d) as well, while the legend in (b) applies to (c), (e), and (f) as well.

of the presence of $\mathrm{NO}_{\mathrm{x}}$ in the $\mathrm{OH}$ oxidation experiment, some compounds are organonitrates (bound to $\mathrm{NO}_{3}^{-}$, light blue). In the CI-APi-TOF spectra, such compounds share the same elemental composition with oxidised organics bound to $\left(\mathrm{HNO}_{3}\right) \mathrm{NO}_{3}^{-}$from the $\mathrm{CI}$. Even if they have been labelled so, one may not totally exclude the detection of organonitrates bound to $\mathrm{NO}_{3}^{-}$by the CI-APi-TOF.

At higher masses, the bands contain clusters of organic molecules and inorganic ions $\left(\left(\mathrm{H}_{2} \mathrm{SO}_{4}\right)_{n} \mathrm{HSO}_{4}^{-}(n=\right.$ $0,1,2)$ or $\left.\mathrm{NO}_{3}^{-}\right)$. The binding to sulfuric acid clusters $\left(\left(\mathrm{H}_{2} \mathrm{SO}_{4}\right)_{n} \mathrm{HSO}_{4}^{-}(n=1,2)\right)$ is more pronounced for the ozonolysis-only experiment, even though $\mathrm{H}_{2} \mathrm{SO}_{4}$ levels are similar in both experiments (within a factor of 2).

Clusters detected in the positive spectra (a and d) almost exclusively consist of an $\alpha$-pinene oxidation product and a cation (either a proton $\left(\mathrm{H}^{+}\right)$, an ammonium $\left(\mathrm{NH}_{4}^{+}\right)$, or a dimethylaminium $\left(\mathrm{C}_{2} \mathrm{H}_{8} \mathrm{~N}^{+}\right)$), even for the higher masses. They rarely contain neutral ammonia $\left(\mathrm{NH}_{3}\right)$ or dimethylamine $\left(\mathrm{C}_{2} \mathrm{H}_{7} \mathrm{~N}\right)$ molecules. In Fig. 2, no distinction is made between $\mathrm{NH}_{4}^{+}$and $\mathrm{C}_{2} \mathrm{H}_{8} \mathrm{~N}^{+}$containing clusters.

The third band (" $\mathrm{C}_{30}$ ") is not evident in spectra of anions ( $\mathrm{b}$ and e) and the fourth band (" $\mathrm{C}_{40}$ ") is absent. These have been observed by Schobesberger et al. (2013), though in a different reaction system $(\mathrm{OH}$ oxidation of pinanediol, a first-generation oxidation product of $\alpha$-pinene). This suggests that $\mathrm{OH}$ oxidation of first-generation products of $\alpha$ pinene ozonolysis is conducive to the binding of $\mathrm{H}_{2} \mathrm{SO}_{4}$ for the compounds of the third and fourth band in the negative spectra. Nevertheless, " $\mathrm{C}_{30}$ " and " $\mathrm{C}_{40}$ " bands are seen in spectra of positive clusters ( $a$ and $d$ ) in both cases with a weaker signal for the third and fourth bands compared to the first two. However, as none of these bands is observed for the neutral clusters ( $\mathrm{c}$ and $\mathrm{f}$ ) for either oxidation conditions, these large compounds evidently do not form stable clusters with $\mathrm{NO}_{3}^{-}$. This means that if large oxidised organic compounds are formed in the gas phase before being protonated or binding to ions, their functionalities favour binding with $\mathrm{NH}_{4}^{+}$or $\mathrm{C}_{2} \mathrm{H}_{8} \mathrm{~N}^{+}$rather than with $\mathrm{NO}_{3}^{-}$or $\left(\mathrm{H}_{2} \mathrm{SO}_{4}\right)_{n} \mathrm{HSO}_{4}^{-}$ $(n=0,1,2)$, pointing towards compounds with acidic (carboxylic) functionalities.

\subsection{Average carbon oxidation state, $\overline{\mathrm{OS}}_{\mathrm{C}}$}

The average carbon oxidation state $\left(\overline{\mathrm{OS}}_{\mathrm{C}}\right)$ of the identified oxidised organic compounds in the clusters for both oxidation conditions is presented in Fig. 3 (dark grey symbols and lines). $\overline{\mathrm{OS}}_{\mathrm{C}}$ has been derived by averaging all peaks with retrieved elemental composition, weighted by signal intensity, for groups of compounds (e.g. $\mathrm{C}_{10}, \mathrm{C}_{20}$ ) and for each instru- 

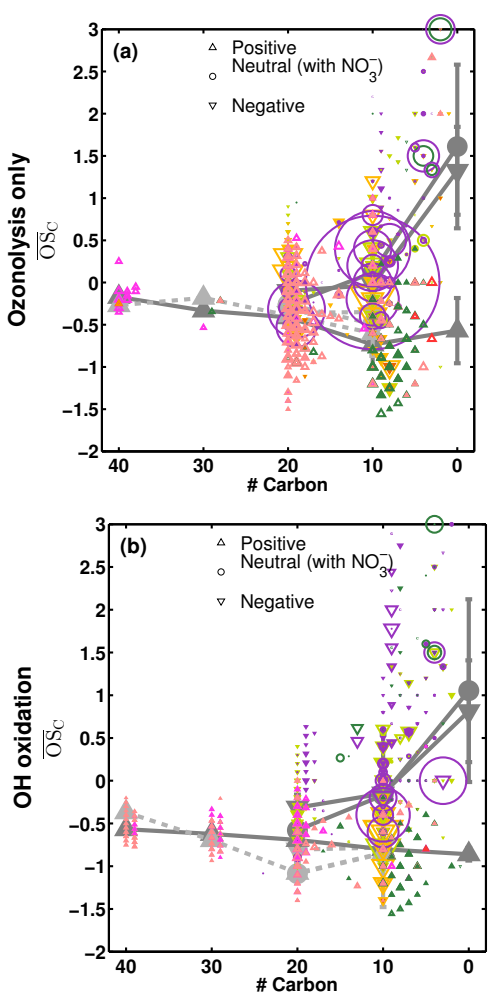

Figure 3. Mean carbon oxidation state $\left(\overline{\mathrm{OS}}_{\mathrm{C}}\right)$ for pure ozonolysis (a) and $\mathrm{OH}$ oxidation (b) as a function of the number of carbon atoms for each identified oxidised organic compound in clusters for the three instruments. The shapes of the markers indicate which type of clusters is depicted, and the colours are the same as in Fig. 2. The weighted means and standard deviations for the various bands of positive and negative APi-TOF $(\mathrm{C}<8, \mathrm{C}=8-12, \mathrm{C}=18$ $20, C=28-30$, and $C=38-40)$ are indicated with large grey symbols and bars. See main text for detailed discussion.

ment separately. Weighted averages and standard deviations for bands for each instrument are shown as large grey symbols and bars, respectively. Bands are defined as following: " $\mathrm{C}_{0}$ " for $\mathrm{C}<8, " \mathrm{C}_{10}$ " for $\mathrm{C}=8-12, " \mathrm{C}_{20}$ " for $\mathrm{C}=18-20$, " $\mathrm{C}_{30}$ " for $\mathrm{C}=28-30$, and " $\mathrm{C}_{40}$ " for $\mathrm{C}=38-40$. The sensitivity of each ion does not change dramatically within a band so that it is assumed to be similar for all signals used for each average.

Note that weighted averages for the CI-APi-TOF instrument are not representative of the whole population of neutral molecules (see discussion in the next section). However, because $\mathrm{NO}_{3}^{-}$is an important atmospheric ion, CI-APi-TOF results are also discussed in this section. Ehn et al. (2012) observed that oxidised compounds bind naturally to $\mathrm{NO}_{3}^{-}$at low levels of sulfuric acid, for instance during night-time.

The $\overline{\mathrm{OS}}_{\mathrm{C}}$ trends are similar for both oxidation conditions. The values for the " $\mathrm{C}_{0}$ " band are high (i.e. compounds are more oxidised) for negative and neutral species but below zero (i.e. compounds are less oxidised) for the positive species. The compounds detected in the neutral channel are slightly more oxidised. These values converge (decreasing for negative and neutral species and increasing for positive species) and are about the same for the " $\mathrm{C}_{20}$ " band. Averaged $\overline{\mathrm{OS}}_{\mathrm{C}}$ for the " $\mathrm{C}_{20}$ " band is about -0.3 in the ozonolysis-only experiment and about -0.7 in the $\mathrm{OH}$ oxidation experiment, independent of which ions the oxidised organic compounds are bound to.

Note that the operationally defined $\overline{\mathrm{OS}}_{\mathrm{C}}$ neglects the effect of peroxide functionalities $(-\mathrm{OOH})$, which one expects to be abundant for low $\mathrm{NO}_{\mathrm{x}}$ levels as it is the case in the present experiments. We derived a formula to estimate the lowest value of $\overline{\mathrm{OS}}_{\mathrm{C}}$, maximising the number of hydroperoxide functional groups for compounds with exactly $n \cdot 10$ carbon atoms $(n=1,2,3,4): \overline{\mathrm{OS}}_{\mathrm{C}, \max (\mathrm{OOH})} \approx n \cdot 0.8+\mathrm{O}: \mathrm{C}-1.5 \cdot(\mathrm{H}: \mathrm{C})$. It derives from the minimum number of carbonyl $(\mathrm{C}=\mathrm{O})$ functionalities required based on the number of hydrogen atoms, knowing that the elemental composition of $\alpha$-pinene, the starting material is $\mathrm{C}_{10} \mathrm{H}_{16}$. Therefore, this approach cannot be generalised, and it remains an approximation, as one cannot precisely derive $\overline{\mathrm{OS}}_{\mathrm{C}}$ without knowing the exact structure of the analysed compounds. This is represented in Fig. 3 by light grey bars, symbols, and dashed lines. These values vary marginally from operationally defined $\overline{\mathrm{OS}}_{\mathrm{C}}$ values for ozonolysis. The variation is slightly higher from compounds with 20 and 40 carbon atoms in the $\mathrm{OH}$ oxidation experiment.

The next sections focus on the differences in elemental composition and clustering behaviour of newly formed compounds for either oxidation conditions. For the sake of clarity, only a detailed analysis of clusters containing $\mathrm{C}_{10}$ and $\mathrm{C}_{20}$ oxidised organic compounds is presented.

\subsection{Elemental composition of selected oxidised organics}

The identified $\mathrm{C}_{10}$ and $\mathrm{C}_{20}$ oxidised organic compounds from the clusters with highest signal were grouped regardless of which inorganic ions they were bound to (Figs. 4 and 5). These stacked bars represent the clusters' peak area in the mass spectra in which the oxidised organic compounds were identified. No quantitative comparison is made. From both overview figures, charged species are discussed first, and later compared to neutral species, comparing both oxidation pathways. In the end, time series of some clusters are presented in order to understand their temporal evolution.

\subsubsection{Ions}

The differences in compound distribution between pure ozonolysis using an $\mathrm{OH}$ scavenger $(\mathrm{a}-\mathrm{c})$ and $\mathrm{OH}$ oxidation (d-f) for positively (a and d) and negatively (b and e) charged clusters containing a $\mathrm{C}_{10}$ oxidised compound are illustrated in Fig. 4. The range of compounds measured is similar for both experiments, but their distribution patterns differ. For positively charged species (a and d), elemental compositions $\mathrm{C}_{10} \mathrm{H}_{14} \mathrm{O}_{1-7}$, and $\mathrm{C}_{10} \mathrm{H}_{16} \mathrm{O}_{2-8}$ have been iden- 


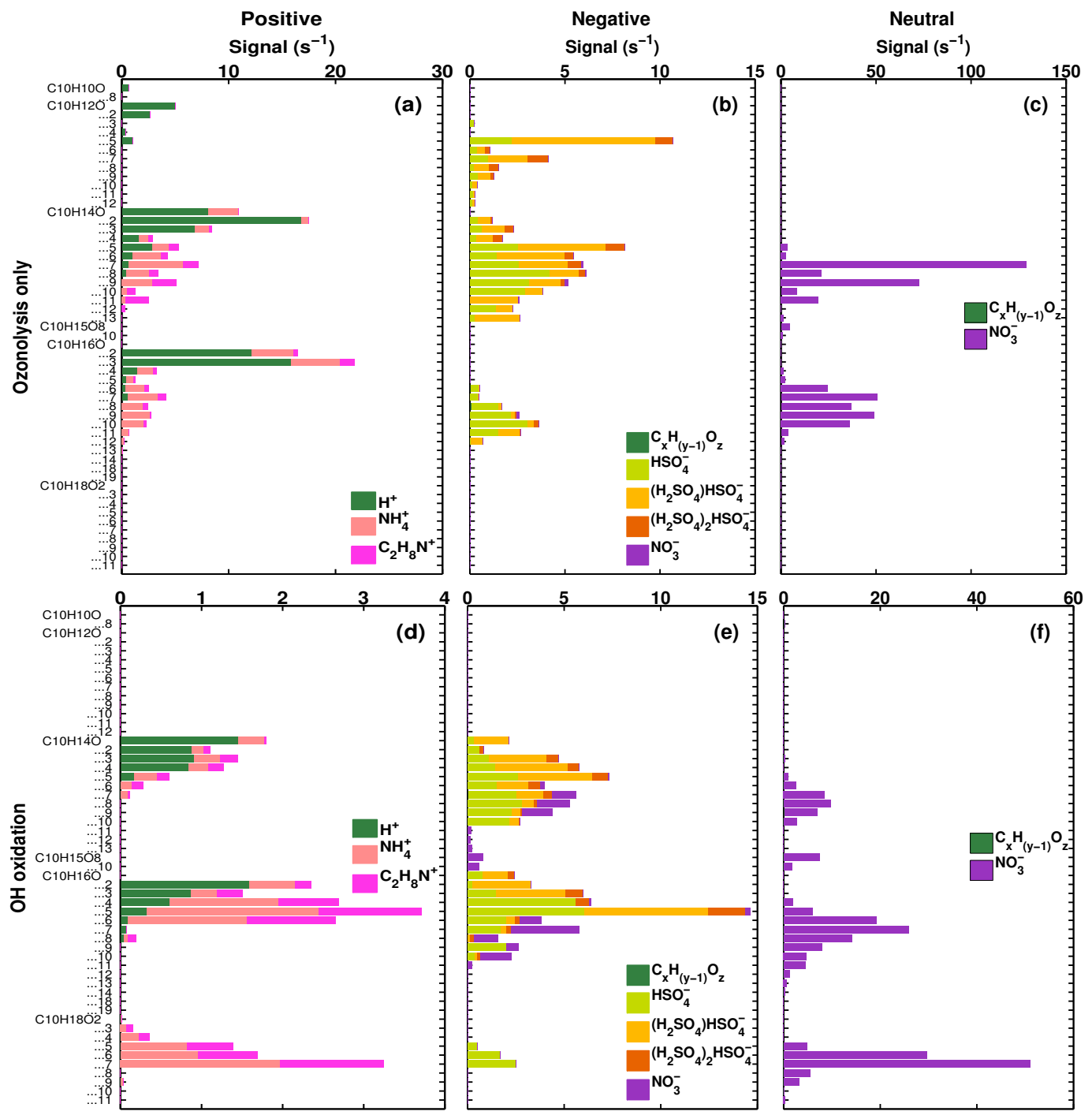

Figure 4. Stacked peak area for observed clusters containing $\mathrm{C}_{10} \mathrm{H}_{\mathrm{b}} \mathrm{O}_{\mathrm{c}}$ according to core ion(s) of positive (a and d), negative (b and e), and neutral (c and f) clusters obtained from $\alpha$-pinene ozonolysis with $\mathrm{OH}$ scavenger $(\mathbf{a}-\mathbf{c})$ and $\alpha$-pinene oxidation by $\mathrm{OH}$ only $(\mathbf{d}-\mathbf{f})$.

tified in both experiments, whereas the elemental composition $\mathrm{C}_{10} \mathrm{H}_{18} \mathrm{O}_{2-9}$, for instance, is only seen in the $\mathrm{OH}$ oxidation experiment. For the negatively charged species $(\mathrm{b}$ and e) the $\mathrm{C}_{10} \mathrm{H}_{12} \mathrm{O}_{5-12}, \mathrm{C}_{10} \mathrm{H}_{14} \mathrm{O}_{2-13}$ and $\mathrm{C}_{10} \mathrm{H}_{16} \mathrm{O}_{6-11}$ compositions are present in both experiments, whereas compositions $\mathrm{C}_{10} \mathrm{H}_{16} \mathrm{O}_{1-5}$ are typical for $\mathrm{OH}$ oxidation. Due to the previously addressed issue with $\mathrm{O}_{6}$ and $\mathrm{SO}_{4}$ having very close masses, the attribution in the negative spectra of composition such as $\left(\mathrm{C}_{10} \mathrm{H}_{\mathrm{b}} \mathrm{O}_{\mathrm{c}}\right)\left(\mathrm{H}_{2} \mathrm{SO}_{4}\right)_{\mathrm{n}} \mathrm{HSO}_{4}^{-}$remains ambiguous as their signal is small and interferes with $\left(\mathrm{C}_{10} \mathrm{H}_{\mathrm{b}+2} \mathrm{O}_{\mathrm{c}+6}\right)\left(\mathrm{H}_{2} \mathrm{SO}_{4}\right)_{n-1} \mathrm{HSO}_{4}^{-}(n=1,2)$.

The corresponding analysis for the second band $\left(\mathrm{C}_{20} \mathrm{com}-\right.$ pounds) reveals clear differences between ozonolysis and $\mathrm{OH}$ oxidation in the formation of ion clusters (Fig. 5). Pure ozonolysis leads to mostly $\mathrm{C}_{20} \mathrm{H}_{30} \mathrm{O}_{c}$ products, with higher signals for compounds with an even number of oxy- gen atoms in the positive spectra (a), whereas $\mathrm{OH}$ oxidation leads to $\mathrm{C}_{20} \mathrm{H}_{30,32,34} \mathrm{O}_{\mathrm{c}}$ without preference for compounds with even numbers of oxygen atoms (d). In the negative spectra (b and e), the preference for compounds with even number is less evident, and the range of $\mathrm{O}: \mathrm{C}$ is broader. In the ozonolysis experiment (b), it remains ambiguous if $\left(\mathrm{C}_{20} \mathrm{H}_{\mathrm{b}} \mathrm{O}_{\mathrm{c}}\right)\left(\mathrm{H}_{2} \mathrm{SO}_{4}\right)_{n} \mathrm{HSO}_{4}^{-}(n=1,2)$ are formed by aggregation of two $\mathrm{C}_{10}$ containing clusters (neutral and negative, Eq. 1), or by the reaction of a formed $\mathrm{C}_{20}$ compound with a sulfuric acid cluster (Eq. 2). The addition of a sulfuric acid molecule to an existing bisulfate cluster (Eq. 3) is also possible. The reaction pathways do not exclude each other and might coexist (see also Sect. 4). 

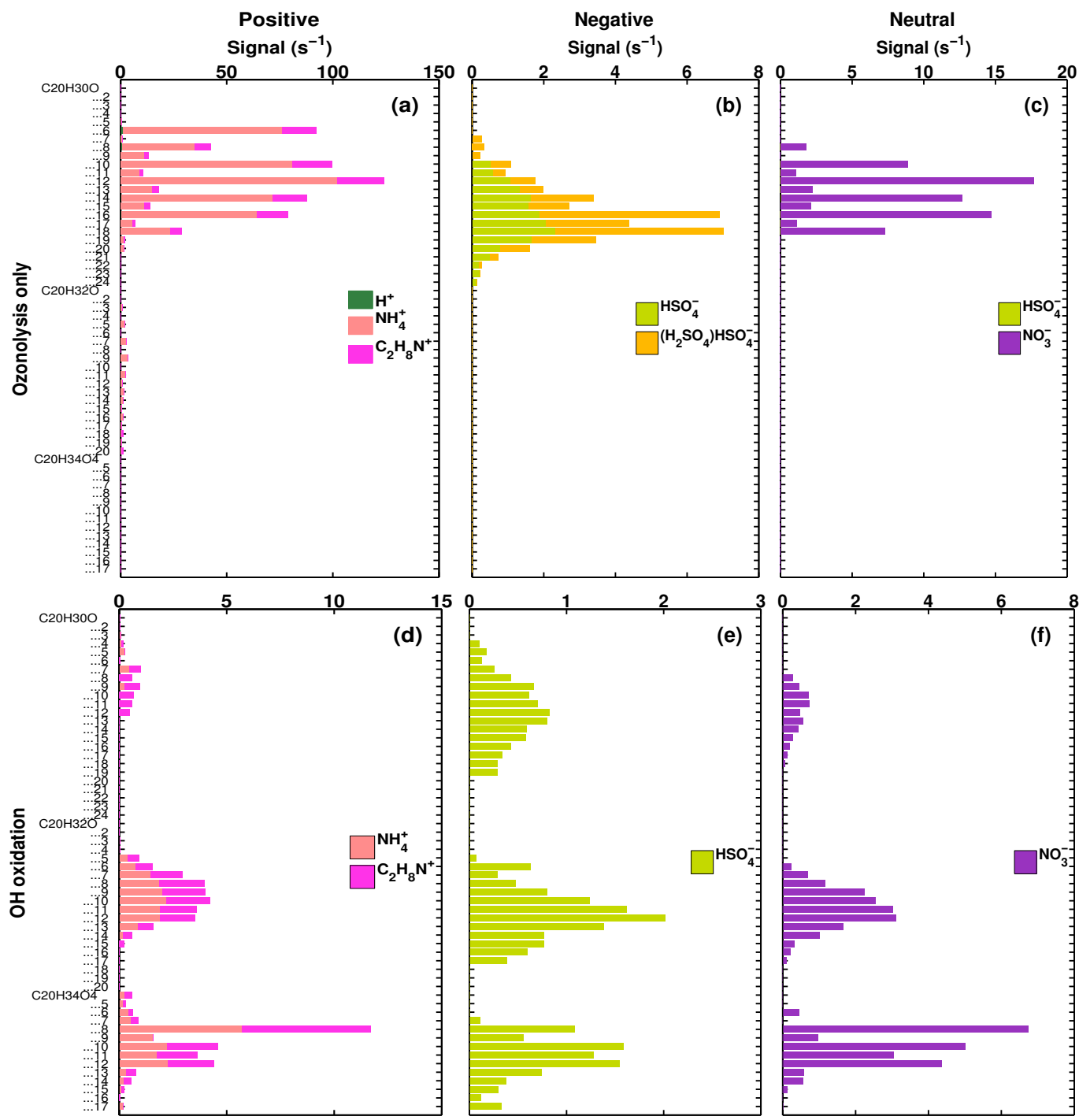

Figure 5. Stacked peak area for observed clusters containing $\mathrm{C}_{20} \mathrm{H}_{\mathrm{b}} \mathrm{O}_{\mathrm{c}}$ according to core ion(s) of positive (a and d), negative (b and e), and neutral (c and f) clusters obtained from $\alpha$-pinene ozonolysis with $\mathrm{OH}$ scavenger $(\mathbf{a}-\mathbf{c})$ and $\alpha$-pinene oxidation by $\mathrm{OH}$ only $(\mathbf{d}-\mathbf{f})$.

$$
\begin{gathered}
\left(\mathrm{C}_{10} \mathrm{H}_{\mathrm{b}} \mathrm{O}_{\mathrm{c}}\right) \mathrm{HSO}_{4}^{-}+\left(\mathrm{C}_{10} \mathrm{H}_{\mathrm{d}} \mathrm{O}_{\mathrm{e}}\right) \mathrm{H}_{2} \mathrm{SO}_{4} \rightarrow \\
\left(\mathrm{C}_{20} \mathrm{H}_{\mathrm{b}+\mathrm{d}} \mathrm{O}_{\mathrm{c}+\mathrm{e}}\right)\left(\mathrm{H}_{2} \mathrm{SO}_{4}\right) \mathrm{HSO}_{4}^{-} \\
\mathrm{C}_{20} \mathrm{H}_{\mathrm{b}} \mathrm{O}_{\mathrm{c}}+\left(\mathrm{H}_{2} \mathrm{SO}_{4}\right) \mathrm{HSO}_{4}^{-} \rightarrow \\
\left(\mathrm{C}_{20} \mathrm{H}_{\mathrm{b}} \mathrm{O}_{\mathrm{c}}\right)\left(\mathrm{H}_{2} \mathrm{SO}_{4}\right) \mathrm{HSO}_{4}^{-} \\
\left(\mathrm{C}_{20} \mathrm{H}_{\mathrm{b}} \mathrm{O}_{\mathrm{c}}\right) \mathrm{HSO}_{4}^{-}+\left(\mathrm{H}_{2} \mathrm{SO}_{4}\right) \rightarrow \\
\left(\mathrm{C}_{20} \mathrm{H}_{\mathrm{b}} \mathrm{O}_{\mathrm{c}}\right)\left(\mathrm{H}_{2} \mathrm{SO}_{4}\right) \mathrm{HSO}_{4}^{-}
\end{gathered}
$$

It remains unclear why such clusters with additional neutral molecules are not observed in the $\mathrm{OH}$ oxidation experiment. This may be due to the lower concentration of $\mathrm{H}_{2} \mathrm{SO}_{4}$ in this experiment, or because their signals are low and hidden by isobaric clusters of a different composition.
These results illustrate how the oxidation processes modify the proton affinity and the clustering behaviour of the oxidation products of $\alpha$-pinene. The addition of functional groups modifies the interaction with protons, ions and ionic clusters. Figure 1 presents an overview of both oxidation pathways (with examples of possible structures for the observed products). Despite different mechanisms in the early steps, peroxy radicals are produced under both oxidation conditions and will react in a similar way with various available reaction partners independent of their formation pathway (Fig. 1, Reactions 1 to 5 in the green box). The decomposition reaction of alkyloxy radicals (from reaction 4) and intramolecular $\mathrm{H}$-abstractions followed by reaction with $\mathrm{O}_{2}$ (reaction 5) lead again to peroxy radicals (and acylperoxy radicals), which can again react via reactions 1 to 5 in an iterative manner (red arrows). Terminal reactions lead to 
(extremely) low volatility organic compounds ((E)LVOCs). In our experiments, $\mathrm{NO}_{\mathrm{x}}$ is only relevant for the $\mathrm{OH}$ oxidation pathway. No explicit structure is given for products of intramolecular $\mathrm{H}$-abstraction, as it is not yet known which $\mathrm{H}$ atom would be abstracted first. Termination reaction branching ratios leading to the various functionalities are influenced by $\mathrm{HO}_{2}, \mathrm{RO}_{2}$ and $\mathrm{NO}_{\mathrm{x}}$ levels. Therefore, there is a minor difference in functional groups for species with a lower number of oxygen atoms: ozonolysis favours carbonyl functional groups (ketones, aldehydes), while $\mathrm{OH}$ oxidation produces hydroxyl (alcohols) functionalities (Atkinson, 2000; Vereecken et al., 2012; Taatjes et al., 2013). However, for multifunctional species (more than five oxygen atoms, ELVOCs), no particular functional group is dominant.

Bipolar charging probabilities determined for aerosol particles are sometimes extrapolated down to $1 \mathrm{~nm}$ diameters (e.g. Jiang et al., 2011) ignoring the role of chemical composition. Although the present results do not necessarily apply to all types of clusters, they do suggest that this extrapolation is valid down to around $1.5 \mathrm{~nm}$ in mobility diameter, which is roughly the size of the detected $\mathrm{C}_{20}$ containing clusters (Ehn et al., 2011). Below this size, compounds clearly behave differently depending on polarity and charger ion composition due to the limited type and number of functional groups, so that they bind selectively to specific ions.

Ehn et al. (2012) identified $\mathrm{C}_{10} \mathrm{H}_{14} \mathrm{O}_{7-11,13}$, $\mathrm{C}_{10} \mathrm{H}_{16} \mathrm{O}_{7-11}, \quad \mathrm{C}_{20} \mathrm{H}_{30} \mathrm{O}_{12-16,18}$, and $\mathrm{C}_{20} \mathrm{H}_{32} \mathrm{O}_{11,13,15}$ in $\alpha$-pinene ozonolysis chamber experiments (and a subset of these in the boreal forest site in Hyytiälä, Finland). All of these were also identified during our study in either experiment.

\subsubsection{Neutral species}

The clusters containing $\mathrm{C}_{10}$ and $\mathrm{C}_{20}$ oxidised compounds from the ozonolysis only experiment (c) and the $\mathrm{OH}$ oxidation (f) are depicted in Figs. 4 and 5.

$\mathrm{C}_{10} \mathrm{H}_{15} \mathrm{O}_{8,10}$ (bound to $\mathrm{NO}_{3}^{-}$) are seen in the neutral spectra of the $\mathrm{OH}$ oxidation experiment (Fig. 4f). They are also seen in the negative spectra (Fig. 4e).

Comparing the mass spectra of the neutral species with the previously discussed plots from the negative clusters, it appears that the natural ionisation happening in the chamber with $\mathrm{HSO}_{4}^{-}$is less selective than the chemical ionisation with $\mathrm{NO}_{3}^{-}$in the CI-APi-TOF ion source. Therefore, not all the neutral species appear in the spectra of the neutral clusters. The detected compounds represent ELVOCs though and were shown to be proportional to the (total) concentration of oxidised compounds (Ehn et al., 2014). Therefore, for a comprehensive detection of $\alpha$-pinene oxidation products and their mechanistic interpretation, $\mathrm{HSO}_{4}^{-}$seems to perform better than $\mathrm{NO}_{3}^{-}$as an ionisation reagent

Schobesberger et al. (2013) presented a similar analysis for oxidation reactions of pinanediol with $\mathrm{OH}$ (and high $\mathrm{H}_{2} \mathrm{SO}_{4}$ levels). No CI-APi-TOF was used for those experi- ments and the authors claimed that the composition of neutral clusters was similar to that of negatively charged clusters. Even though this statement may be true, it cannot be shown with only one type of chemical ionisation.

While the distribution of clusters in the neutral spectra compared to the positive and negative spectra is different for $\mathrm{C}_{10}$ compounds, it is almost identical for the $\mathrm{C}_{20}$ compounds. Therefore, $\mathrm{C}_{20}$ compounds independently of their formation pathways display a similar reactivity towards $\mathrm{NH}_{4}^{+}$, $\mathrm{C}_{2} \mathrm{H}_{8} \mathrm{~N}^{+}, \mathrm{HSO}_{4}^{-}$and $\mathrm{NO}_{3}^{-}$, even though the distribution is shifted towards slightly more oxidised compounds in the neutral spectra, especially for $\mathrm{C}_{20} \mathrm{H}_{30,32} \mathrm{O}_{c}$. In our experiments, the negative spectra are sensitive to a broader range of $\mathrm{O}: \mathrm{C}$, in particular for $\mathrm{C}_{20} \mathrm{H}_{30} \mathrm{O}_{\mathrm{c}}$.

\section{Time series of clusters}

Normalised time series have been derived for all three instruments to investigate formation mechanisms. The time resolution is 2 min except for positive data ( $1 \mathrm{~min}$ ) and negative $\mathrm{OH}$ oxidation data $(5 \mathrm{~min})$. These have been set in order to optimise the signal-to-noise ratio in each of the spectra.

Analysis of positive $\mathrm{C}_{20}$ containing clusters in the ozonolysis experiment shows that most oxidised compounds (up to $\mathrm{O}_{18}$, not shown) appear almost immediately after the beginning of the experiment (vertical black line) and reach their maximum concentration the earliest (Fig. 6). This is observed for clusters of $\mathrm{C}_{20} \mathrm{H}_{30} \mathrm{O}_{\mathrm{c}}$ with either $\mathrm{NH}_{4}^{+}$or $\mathrm{C}_{2} \mathrm{H}_{8} \mathrm{~N}^{+}$. The signals of the clusters containing the most oxidised compounds decrease after reaching their maximum, whereas the signals of the other clusters level off. This is due to the change in $\alpha$-pinene: $\mathrm{O}_{3}$ ratio, as the $\mathrm{O}_{3}$ level is kept constant during the experiment, while the $\alpha$-pinene mixing ratio slowly increases (no steady-state conditions). Therefore, when $\alpha$-pinene is very low, formation rates of the various oxidation products change because fewer termination reactions (with $\mathrm{RO}_{2}$ ) happen, allowing further oxidation by successive intramolecular H-shifts as suggested by Ehn et al. (2014); see Fig. 1. This observation is in line with chamber experiments (Shilling et al., 2009; Ng et al., 2010; Pfaffenberger et al., 2013), showing that higher O : C of SOA is achieved with low $\alpha$-pinene levels. This result contrasts with the view that the most oxidised organic compounds are formed only after long oxidants exposure time (e.g. Jimenez et al., 2009; Andreae, 2009; Kang et al., 2011). Highly oxidised organic compounds can also be formed very quickly, depending on the oxidation conditions. The different behaviour of oxidised organic compounds with the same elemental composition bound to $\mathrm{NH}_{4}^{+}$and $\mathrm{C}_{2} \mathrm{H}_{8} \mathrm{~N}^{+}$can be explained by either the different formation rates of these clusters (both cations competing and $\mathrm{NH}_{4}^{+}$seemingly forming more stable clusters) or by the fact that there can be various compounds with the same elemental composition but different chemical properties. 

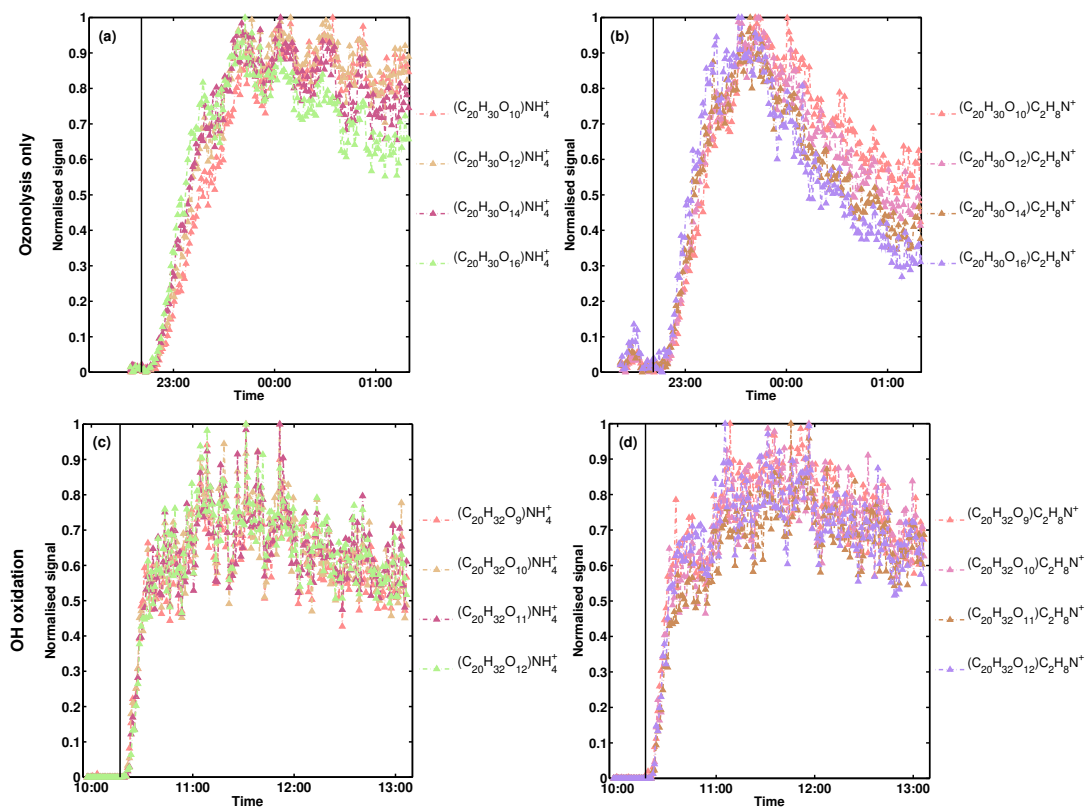

Figure 6. Time series of observed positive clusters containing $\mathrm{C}_{20} \mathrm{H}_{30,32} \mathrm{O}_{\mathrm{c}}$ oxidised compounds bound to $\mathrm{NH}_{4}^{+}(\mathbf{a}$ and $\mathbf{c})$ and $\mathrm{C}_{2} \mathrm{H}_{8} \mathrm{~N}^{+}(\mathbf{b}$ and $\mathbf{d}$ ) for $\alpha$-pinene pure ozonolysis (a-b) and pure $\mathrm{OH}$ oxidation (c-d). The vertical black line marks the beginning of the experiment.

For the $\mathrm{OH}$ oxidation experiment the $\alpha$-pinene concentration is high from the beginning of the run and $\mathrm{OH}$ is produced from HONO photolysis by UV light. Note that the $\alpha$-pinene concentration decreases during the experiment, so that steady-state conditions are achieved after about $3 \mathrm{~h}$ of oxidation only. Moreover, various oxidised organic compounds compete to form stable clusters with the available ions. In this case, the signals for the presented positive clusters containing $\mathrm{C}_{20} \mathrm{H}_{32} \mathrm{O}_{c}$ (with either $\mathrm{NH}_{4}^{+}$or $\mathrm{C}_{2} \mathrm{H}_{7} \mathrm{~N}^{+}$) rise almost simultaneously so that it is not possible to tell if one of them is formed earlier, even at $1 \mathrm{~min}$ time resolution. Trying to increase the time resolution to observe which signals increase first would lead to an overly low signal-to-noise ratio. A similar (but less clear) trend is observed as well in the neutral spectra (Fig. 7).

\section{Conclusions}

Oxidation of $\alpha$-pinene was conducted in the CLOUD chamber. The simultaneous use of three different mass spectrometers provides a unique insight into the chemical reaction mechanisms happening in the early stage of $\alpha$-pinene oxidation and molecular cluster formation.

Charged clusters consist of oxidised organic compounds binding to a core ion (bisulfate or nitrate for negative clusters and hydronium, ammonium, or aminium for positive clusters). Molecular clusters including additional sulfuric acid molecules have also been detected in the negative spectra for ozonolysis, while in the positive spectra, even clusters with high masses rarely contain neutral ammonia or dimethy-
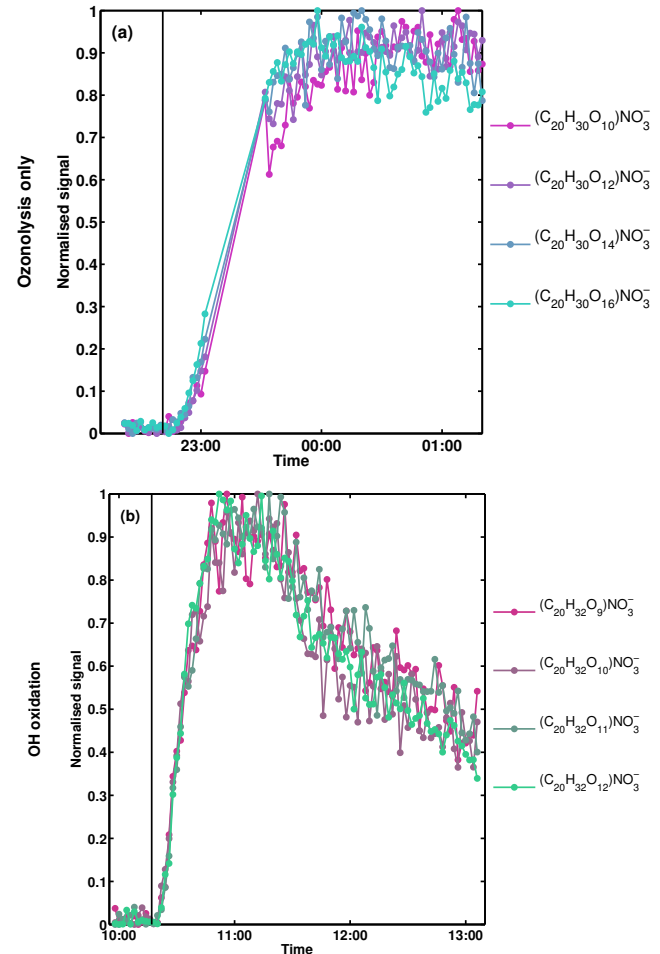

Figure 7. Time series of observed neutral clusters containing $\mathrm{C}_{20} \mathrm{H}_{30} \mathrm{O}_{\mathrm{c}}$ oxidised compounds for $\alpha$-pinene pure ozonolysis (a) and containing $\mathrm{C}_{20} \mathrm{H}_{32} \mathrm{O}_{c}$ for pure $\mathrm{OH}$ oxidation (b). The vertical black line marks the beginning of the experiment. 
lamine molecules. The results show the selectivity of this chemical ionisation process. Especially the difference between ionisation with $\mathrm{NO}_{3}^{-}$and $\mathrm{HSO}_{4}^{-}$can be seen from the broader range of $\mathrm{C}_{10}$ oxidised compounds observed in the negative spectra compared to the neutral one. The cluster distribution of the $\mathrm{C}_{20}$ is very similar for all instruments, showing that due to the many functional groups of these species, their affinities towards the various ions present are similar. This also implies that for the analysis of atmospheric clusters containing oxidised organic clusters, the combination of APiTOF and CI-APi-TOF mass spectrometers with varying ionisation reagent is important in order to capture a comprehensive picture of formed products, in particular for low molar mass products. Oxidised organic compounds $\left(\mathrm{C}_{20}\right)$ with large molar mass can be similarly charged by various ions due to their many functional groups, suggesting that the ionisation starts to be independent of the charging mechanism. Even if the two oxidation mechanisms differ in their first step, they both lead to the formation of peroxy radicals, which produce multifunctional oxidised organic compounds. For compounds containing a low number of oxygen atoms, ozonolysis products tend to possess more carbonyl functionalities while $\mathrm{OH}$ oxidation products have more hydroxyl functionalities and preferentially get protonated or form clusters with cations. However, there is no clear functional group distribution for the compounds with a larger degree of oxidation. Their functionalities depend on the termination reactions with $\mathrm{HO}_{2}, \mathrm{RO}_{2}$, or $\mathrm{NO}_{\mathrm{x}}$ and they bind with cations as well as with anions.

Other differences could be highlighted between the oxidised organic compounds from ozonolysis and $\mathrm{OH}$ oxidation besides their clustering behaviour. For instance, the mean carbon oxidation state $\left(\overline{\mathrm{OS}}_{\mathrm{C}}\right)$ of the oxidised compounds in the clusters when averaged by bands is higher for ozonolysis than for $\mathrm{OH}$ oxidation experiment. This difference is likely due to $\mathrm{NO}_{\mathrm{x}}$ present in the $\mathrm{OH}$ oxidation experiment, though.

Time series of the signals of selected clusters indicate that early steps of ozonolysis lead to the formation of highly oxidised compounds. This is due to the low $\mathrm{RO}_{2}$ concentrations, resulting from low $\alpha$-pinene levels. This allows $\mathrm{RO}_{2}$ to react intra-molecularly (by $\mathrm{H}$ abstractions followed by reaction with $\mathrm{O}_{2}$ ) several times before they react with another $\mathrm{RO}_{2}$ to form stable $\mathrm{C}_{10}$ or $\mathrm{C}_{20}$ oxidation products. Therefore their $\mathrm{O}: \mathrm{C}$ is higher. There is consequently no oxidation pathway from low to highly oxidised molecules, but rather a branching of oxidation levels according to oxidation conditions.

Finally, the results presented are limited to the used oxidation conditions in our experiments. Broader ranges of temperatures, relative humidities, $\mathrm{NO}_{\mathrm{x}}$ and $\alpha$-pinene levels need to be investigated to enable generalisation of the conclusions of the present study and refine clustering mechanisms of oxidised organic compounds.
Acknowledgements. We would like to thank CERN for supporting CLOUD with important technical and financial resources, and for providing a particle beam from the CERN Proton Synchrotron. We also thank P. Carrie, L.-P. De Menezes, J. Dumollard, K. Ivanova, F. Josa, I. Krasin, R. Kristic, A. Laassiri, O. S. Maksumov, B. Marichy, H. Martinati, S. V. Mizin, R. Sitals, A. Wasem and $\mathrm{M}$. Wilhelmsson for their important contributions to the experiment. This research has received funding from the EC Seventh Framework Programme (Marie Curie Initial Training Network "CLOUD-ITN" no. 215072, MC-ITN "CLOUD-TRAIN" no. 316662, ERC-Starting "MOCAPAF" grant no. 57360 and ERC-Advanced "ATMNUCLE" grant no. 227463), PEGASOS project funded by the European Commission under the Framework Programme 7 (FP7-ENV-2010-265148), the German Federal Ministry of Education and Research (project nos. 01LK0902A and 01LK1222A), the Swiss National Science Foundation (project nos. 200020_135307 and 206620_141278), the Academy of Finland (Center of Excellence project no. 1118615), the Academy of Finland (135054, 133872, 251427, 139656, 139995, 137749, 141217, 141451), the Finnish Funding Agency for Technology and Innovation, the Väisälä Foundation, the Nessling Foundation, the Austrian Science Fund (FWF; project no. J3198-N21), the Portuguese Foundation for Science and Technology (project no. CERN/FP/116387/2010), the Swedish Research Council, Vetenskapsrådet (grant 2011-5120), the Presidium of the Russian Academy of Sciences and Russian Foundation for Basic Research (grants 08-02-91006-CERN and 12-02-91522-CERN), the U.S. National Science Foundation (grants AGS1136479 and CHE1012293), and the Davidow Foundation. We thank the tofTools team for providing tools for mass spectrometry analysis.

Edited by: J. H. Seinfeld

\section{References}

Almeida, J., Schobesberger, S., Kürten, A., Ortega, I. K., Kupiainen-Määttä, O., Praplan, A. P., Adamov, A., Amorim, A., Bianchi, F., Breitenlechner, M., David, A., Dommen, J., Donahue, N. M., Downard, A., Dunne, E., Duplissy, J., Ehrhart, S., Flagan, R. C., Franchin, A., Guida, R., Hakala, J., Hansel, A., Heinritzi, M., Henschel, H., Jokinen, T., Junninen, H., Kajos, M., Kangasluoma, J., Keskinen, H., Kupc, A., Kurtén, T., Kvashin, A. N., Laaksonen, A., Lehtipalo, K., Leiminger, M., Leppä, J., Loukonen, V., Makhmutov, V., Mathot, S., McGrath, M. J., Nieminen, T., Olenius, T., Onnela, A., Petäjä, T., Riccobono, F., Riipinen, I., Rissanen, M., Rondo, L., Ruuskanen, T., Santos, F. D., Sarnela, N., Schallhart, S., Schnitzhofer, R., Seinfeld, J. H., Simon, M., Sipilä, M., Stozhkov, Y., Stratmann, F., Tomé, A., Tröstl, J., Tsagkogeorgas, G., Vaattovaara, P., Viisanen, Y., Virtanen, A., Vrtala, A., Wagner, P. E., Weingartner, E., Wex, H., Williamson, C., Wimmer, D., Ye, P., Yli-Juuti, T., Carslaw, K. S., Kulmala, M., Curtius, J., Baltensperger, U., Worsnop, D. R., Vehkamäki, H., and Kirkby, J.: Molecular understanding of sulphuric acid-amine particle nucleation in the atmosphere, Nature, 502, 359-363, doi:10.1038/nature12663, 2013.

Andreae, M. O.: A new look at aging aerosols, Science, 326, $1493-$ 1494, doi:10.1126/science.1183158, 2009. 
Atkinson, R.: Atmospheric chemistry of VOCs and $\mathrm{NO}_{\mathrm{x}}$, Atmos. Environ., 34, 2063-2101, doi:10.1016/S1352-2310(99)00460-4, 2000.

Bianchi, F., Praplan, A. P., Sarnela, N., Dommen, J., Kürten, A., Ortega, I. K., Schobesberger, S., Junninen, H., Simon, M., Tröstl, J., Jokinen, T., Sipilä, M., Adamov, A., Amorim, A., Almeida, J., Breitenlechner, M., Duplissy, J., Ehrhart, S., Flagan, R. C., Franchin, A., Hakala, J., Hansel, A., Heinritzi, M., Kangasluoma, J., Keskinen, H., Kim, J., Kirkby, J., Laaksonen, A., Lawler, M. J., Lehtipalo, K., Leiminger, M., Makhmutov, V., Mathot, S., Onnela, A., Petäjä, T., Riccobono, F., Rissanen, M. P., Rondo, L., Tomé, A., Virtanen, A., Viisanen, Y., Williamson, C., Wimmer, D., Winkler, P. M., Ye, P., Curtius, J., Kulmala, M., Worsnop, D. R., Donahue, N. M., and Baltensperger, U.: Insight into acid-base nucleation experiments by comparison of the chemical composition of positive, negative, and neutral clusters, Environ. Sci. Technol., 48, 13675-13684, doi:10.1021/es502380b, 2014.

Christoffersen, T., Hjorth, J., Horie, O., Jensen, N., Kotzias, D., Molander, L., Neeb, P., Ruppert, L., Winterhalter, R., Virkkula, A., Wirtz, K., and Larsen, B.: cis-Pinic acid, a possible precursor for organic aerosol formation from ozonolysis of $\alpha$-pinene, Atmos. Environ., 32, 1657-1661, doi:10.1016/S13522310(97)00448-2, 1998.

Claeys, M., Iinuma, Y., Szmigielski, R., Surratt, J. D., Blockhuys, F., Van Alsenoy, C., Böge, O., Sierau, B., GómezGonzález, Y., Vermeylen, R., Van der Veken, P., Shahgholi, M., Chan, A. W. H., Herrmann, H., Seinfeld, J. H., and Maenhaut, W.: Terpenylic acid and related compounds from the oxidation of $\alpha$-Pinene: implications for new particle formation and growth above forests, Environ. Sci. Technol., 43, 6976-6982, doi:10.1021/es9007596, 2009.

Cox, R. A.: The photolysis of gaseous nitrous acid, J. Photochem., 3, 175-188, doi:10.1016/0047-2670(74)80018-3, 1974.

Donahue, N. M., Robinson, A. L., Stanier, C. O., and Pandis, S. N.: Coupled partitioning, dilution, and chemical aging of semivolatile organics, Environ. Sci. Technol., 40, 2635-2643, doi:10.1021/es052297c, 2006.

Donahue, N. M., Epstein, S. A., Pandis, S. N., and Robinson, A. L.: A two-dimensional volatility basis set: 1 . organic-aerosol mixing thermodynamics, Atmos. Chem. Phys., 11, 3303-3318, doi:10.5194/acp-11-3303-2011, 2011.

Eddingsaas, N. C., Loza, C. L., Yee, L. D., Chan, M., Schilling, K. A., Chhabra, P. S., Seinfeld, J. H., and Wennberg, P. O.: $\alpha$-pinene photooxidation under controlled chemical conditions - Part 2: SOA yield and composition in lowand high- $\mathrm{NO}_{\mathrm{x}}$ environments, Atmos. Chem. Phys., 12, 74137427, doi:10.5194/acp-12-7413-2012, 2012a.

Eddingsaas, N. C., Loza, C. L., Yee, L. D., Seinfeld, J. H., and Wennberg, P. O.: $\alpha$-pinene photooxidation under controlled chemical conditions - Part 1: Gas-phase composition in low- and high- $\mathrm{NO}_{\mathrm{x}}$ environments, Atmos. Chem. Phys., 12, 6489-6504, doi:10.5194/acp-12-6489-2012, 2012 b.

Ehn, M., Junninen, H., Petäjä, T., Kurtén, T., Kerminen, V.M., Schobesberger, S., Manninen, H. E., Ortega, I. K., Vehkamäki, H., Kulmala, M., and Worsnop, D. R.: Composition and temporal behavior of ambient ions in the boreal forest, Atmos. Chem. Phys., 10, 8513-8530, doi:10.5194/acp-10-85132010, 2010.
Ehn, M., Junninen, H., Schobesberger, S., Manninen, H. E., Franchin, A., Sipilä, M., Petäjä, T., Kerminen, V.-M., Tammet, H., Mirme, A., Mirme, S., Hõrrak, U., Kulmala, M., and Worsnop, D. R.: An instrumental comparison of mobility and mass measurements of atmospheric small ions, Aerosol Sci. Tech., 45, 522-532, doi:10.1080/02786826.2010.547890, 2011.

Ehn, M., Kleist, E., Junninen, H., Petäjä, T., Lönn, G., Schobesberger, S., Dal Maso, M., Trimborn, A., Kulmala, M., Worsnop, D. R., Wahner, A., Wildt, J., and Mentel, Th. F.: Gas phase formation of extremely oxidized pinene reaction products in chamber and ambient air, Atmos. Chem. Phys., 12, 51135127, doi:10.5194/acp-12-5113-2012, 2012.

Ehn, M., Thornton, J. A., Kleist, E., Sipilä, M., Junninen, H., Pullinen, I., Springer, M., Rubach, F., Tillmann, R., Lee, B., Lopez-Hilfiker, F., Andres, S., Acir, I.-H., Rissanen, M., Jokinen, T., Schobesberger, S., Kangasluoma, J., Kontkanen, J., Nieminen, T., Kurtén, T., Nielsen, L. B., Jørgensen, S., Kjaergaard, H. G., Canagaratna, M., Maso, M. D., Berndt, T., Petäjä, T., Wahner, A., Kerminen, V.-M., Kulmala, M., Worsnop, D. R., Wildt, J., and Mentel, T. F.: A large source of low-volatility secondary organic aerosol, Nature, 506, 476-479, doi:10.1038/nature13032, 2014.

Fuzzi, S., Andreae, M. O., Huebert, B. J., Kulmala, M., Bond, T. C., Boy, M., Doherty, S. J., Guenther, A., Kanakidou, M., Kawamura, K., Kerminen, V.-M., Lohmann, U., Russell, L. M., and Pöschl, U.: Critical assessment of the current state of scientific knowledge, terminology, and research needs concerning the role of organic aerosols in the atmosphere, climate, and global change, Atmos. Chem. Phys., 6, 2017-2038, doi:10.5194/acp-62017-2006, 2006.

Goldstein, A. H. and Galbally, I. E.: Known and unexplored organic constituents in the Earth's atmosphere, Environ. Sci. Technol., 41, 1514-1521, doi:10.1021/es072476p, 2007.

Hallquist, M., Wenger, J. C., Baltensperger, U., Rudich, Y., Simpson, D., Claeys, M., Dommen, J., Donahue, N. M., George, C., Goldstein, A. H., Hamilton, J. F., Herrmann, H., Hoffmann, T., Iinuma, Y., Jang, M., Jenkin, M. E., Jimenez, J. L., KiendlerScharr, A., Maenhaut, W., McFiggans, G., Mentel, Th. F., Monod, A., Prévôt, A. S. H., Seinfeld, J. H., Surratt, J. D., Szmigielski, R., and Wildt, J.: The formation, properties and impact of secondary organic aerosol: current and emerging issues, Atmos. Chem. Phys., 9, 5155-5236, doi:10.5194/acp-9-51552009, 2009.

Hatakeyama, S., Izumi, K., Fukuyama, T., and Akimoto, H.: Reactions of ozone with alpha-pinene and beta-pinene in air: yields of gaseous and particulate products, J. Geophys. Res., 94, 1301313024, doi:10.1029/JD094iD10p13013, 1989.

Hoppel, W., Fitzgerald, J., Frick, G., Caffrey, P., Pasternack, L., Hegg, D., Gao, S., Leaitch, R., Shantz, N., Cantrell, C., Albrechcinski, T., Ambrusko, J., and Sullivan, W.: Particle formation and growth from ozonolysis of $\alpha$-pinene, J. Geophys. Res., 106, 27603-27,618, doi:10.1029/2001JD900018, 2001.

Jiang, J., Chen, M., Kuang, C., Attoui, M., and McMurry, P. H.: Electrical mobility spectrometer using a diethylene glycol condensation particle counter for measurement of aerosol size distributions down to $1 \mathrm{~nm}$, Aerosol Sci. Tech., 45, 510-521, doi:10.1080/02786826.2010.547538, 2011.

Jimenez, J. L., Canagaratna, M. R., Donahue, N. M., Prévôt, A. S. H., Zhang, Q., Kroll, J. H., DeCarlo, P. F., 
Allan, J. D., Coe, H., Ng, N. L., Aiken, A. C., Docherty, K. S., Ulbrich, I. M., Grieshop, A. P., Robinson, A. L., Duplissy, J., Smith, J. D., Wilson, K. R., Lanz, V. A., Hueglin, C., Sun, Y. L., Tian, J., Laaksonen, A., Raatikainen, T., Rautiainen, J., Vaattovaara, P., Ehn, M., Kulmala, M., Tomlinson, J. M., Collins, D. R., Cubison, M. J., Dunlea, J., Huffman, J. A., Onasch, T. B., Alfarra, M. R., Williams, P. I., Bower, K., Kondo, Y., Schneider, J., Drewnick, F., Borrmann, S., Weimer, S., Demerjian, K., Salcedo, D., Cottrell, L., Griffin, R., Takami, A., Miyoshi, T., Hatakeyama, S., Shimono, A., Sun, J. Y., Zhang, Y. M., Dzepina, K., Kimmel, J. R., Sueper, D., Jayne, J. T., Herndon, S. C., Trimborn, A. M., Williams, L. R., Wood, E. C., Middlebrook, A. M., Kolb, C. E., Baltensperger, U., and Worsnop, D. R.: Evolution of organic aerosols in the atmosphere, Science, 326, 1525-1529, doi:10.1126/science.1180353, 2009.

Jokinen, T., Sipilä, M., Junninen, H., Ehn, M., Lönn, G., Hakala, J., Petäjä, T., Mauldin III, R. L., Kulmala, M., and Worsnop, D. R.: Atmospheric sulphuric acid and neutral cluster measurements using CI-APi-TOF, Atmos. Chem. Phys., 12, 4117-4125, doi:10.5194/acp-12-4117-2012, 2012.

Junninen, H., Ehn, M., Petäjä, T., Luosujärvi, L., Kotiaho, T., Kostiainen, R., Rohner, U., Gonin, M., Fuhrer, K., Kulmala, M., and Worsnop, D. R.: A high-resolution mass spectrometer to measure atmospheric ion composition, Atmos. Meas. Tech., 3, 10391053, doi:10.5194/amt-3-1039-2010, 2010.

Kamens, R., Jang, M., Chien, C.-J., and Leach, K.: Aerosol formation from the reaction of $\alpha$-pinene and ozone using a gas-phase kinetics-aerosol partitioning model, Environ. Sci. Technol., 33, 1430-1438, doi:10.1021/es980725r, 1999.

Kanakidou, M., Seinfeld, J. H., Pandis, S. N., Barnes, I., Dentener, F. J., Facchini, M. C., Van Dingenen, R., Ervens, B., Nenes, A., Nielsen, C. J., Swietlicki, E., Putaud, J. P., Balkanski, Y., Fuzzi, S., Horth, J., Moortgat, G. K., Winterhalter, R., Myhre, C. E. L., Tsigaridis, K., Vignati, E., Stephanou, E. G., and Wilson, J.: Organic aerosol and global climate modelling: a review, Atmos. Chem. Phys., 5, 1053-1123, doi:10.5194/acp-51053-2005, 2005.

Kang, E., Toohey, D. W., and Brune, W. H.: Dependence of SOA oxidation on organic aerosol mass concentration and $\mathrm{OH}$ exposure: experimental PAM chamber studies, Atmos. Chem. Phys., 11, 1837-1852, doi:10.5194/acp-11-1837-2011, 2011.

Kendrick, E.: A Mass scale based on $\mathrm{CH}_{2}=14.0000$ for high resolution mass spectrometry of organic compounds, Anal. Chem., 35, 2146-2154, doi:10.1021/ac60206a048, 1963.

Kirkby, J., Curtius, J., Almeida, J., Dunne, E., Duplissy, J., Ehrhart, S., Franchin, A., Gagné, S., Ickes, L., Kürten, A., Kupc, A., Metzger, A., Riccobono, F., Rondo, L., Schobesberger, S., Tsagkogeorgas, G., Wimmer, D., Amorim, A., Bianchi, F., Breitenlechner, M., David, A., Dommen, J., Downard, A., Ehn, M., Flagan, R. C., Haider, S., Hansel, A., Hauser, D., Jud, W., Junninen, H., Kreissl, F., Kvashin, A., Laaksonen, A., Lehtipalo, K., Lima, J., Lovejoy, E. R., Makhmutov, V., Mathot, S., Mikkilä, J., Minginette, P., Mogo, S., Nieminen, T., Onnela, A., Pereira, P., Petäjä, T., Schnitzhofer, R., Seinfeld, J. H., Sipilä, M., Stozhkov, Y., Stratmann, F., Tomé, A., Vanhanen, J., Viisanen, Y., Vrtala, A., Wagner, P. E., Walther, H., Weingartner, E., Wex, H., Winkler, P. M., Carslaw, K. S., Worsnop, D. R., Baltensperger, U., and Kul- mala, M.: Role of sulphuric acid, ammonia and galactic cosmic rays in atmospheric aerosol nucleation, Nature, 476, 429-433, doi:10.1038/nature10343, 2011.

Kroll, J. H. and Seinfeld, J. H.: Chemistry of secondary organic aerosol: formation and evolution of low-volatility organics in the atmosphere, Atmos. Environ., 42, 3593-3624, doi:10.1016/j.atmosenv.2008.01.003, 2008.

Kroll, J. H., Donahue, N. M., Jimenez, J. L., Kessler, S. H., Canagaratna, M. R., Wilson, K. R., Altieri, K. E., Mazzoleni, L. R., Wozniak, A. S., Bluhm, H., Mysak, E. R., Smith, J. D., Kolb, C. E., and Worsnop, D. R.: Carbon oxidation state as a metric for describing the chemistry of atmospheric organic aerosol, Nat. Chem., 3, 133-139, doi:10.1038/nchem.948, 2011.

Kulmala, M., Toivonen, A., Mäkelä, J. M., and Laaksonen, A.: Analysis of the growth of nucleation mode particles observed in Boreal forest, Tellus B, 50, 449-462, doi:10.1034/j.16000889.1998.t01-4-00004.x, 1998.

Kulmala, M., Kontkanen, J., Junninen, H., Lehtipalo, K., Manninen, H. E., Nieminen, T., Petäjä, T., Sipilä, M., Schobesberger, S., Rantala, P., Franchin, A., Jokinen, T., Järvinen, E., Äijälä, M., Kangasluoma, J., Hakala, J., Aalto, P. P., Paasonen, P., Mikkilä, J., Vanhanen, J., Aalto, J., Hakola, H., Makkonen, U., Ruuskanen, T., Mauldin, R. L., Duplissy, J., Vehkamäki, H., Bäck, J., Kortelainen, A., Riipinen, I., Kurtén, T., Johnston, M. V., Smith, J. N., Ehn, M., Mentel, T. F., Lehtinen, K. E. J., Laaksonen, A., Kerminen, V.-M., and Worsnop, D. R.: Direct observations of atmospheric aerosol nucleation, Science, 339, 943-946, doi:10.1126/science.1227385, 2013.

Kupc, A., Amorim, A., Curtius, J., Danielczok, A., Duplissy, J., Ehrhart, S., Walther, H., Ickes, L., Kirkby, J., Kürten, A., Lima, J., Mathot, S., Minginette, P., Onnela, A., Rondo, L., and Wagner, P.: A fibre-optic UV system for $\mathrm{H}_{2} \mathrm{SO}_{4}$ production in aerosol chambers causing minimal thermal effects, J. Aerosol Sci., 42, 532-543, doi:10.1016/j.jaerosci.2011.05.001, 2011.

Kürten, A., Jokinen, T., Simon, M., Sipilä, M., Sarnela, N., Junninen, H., Adamov, A., Almeida, J., Amorim, A., Bianchi, F., Breitenlechner, M., Dommen, J., Donahue, N. M., Duplissy, J., Ehrhart, S., Flagan, R. C., Franchin, A., Hakala, J., Hansel, A., Heinritzi, M., Hutterli, M., Kangasluoma, J., Kirkby, J., Laaksonen, A., Lehtipalo, K., Leiminger, M., Makhmutov, V., Mathot, S., Onnela, A., Petäjä, T., Praplan, A. P., Riccobono, F., Rissanen, M. P., Rondo, L., Schobesberger, S., Seinfeld, J. H., Steiner, G., Tomé, A., Tröstl, J., Winkler, P. M., Williamson, C., Wimmer, D., Ye, P., Baltensperger, U., Carslaw, K. S., Kulmala, M., Worsnop, D. R., and Curtius, J.: Neutral molecular cluster formation of sulfuric acid-dimethylamine observed in real time under atmospheric conditions, P. Natl. Acad. Sci. USA, 111, 15019-15024, doi:10.1073/pnas.1404853111, 2014.

Lee, S. and Kamens, R. M.: Particle nucleation from the reaction of $\alpha$-pinene and $\mathrm{O}_{3}$, Atmos. Environ., 39, 6822-6832, doi:10.1016/j.atmosenv.2005.07.062, 2005.

Ma, Y., Russell, A. T., and Marston, G.: Mechanisms for the formation of secondary organic aerosol components from the gasphase ozonolysis of $\alpha$-pinene, Phys. Chem. Chem. Phys., 10, 4294-4312, doi:10.1039/B803283A, 2008.

Metzger, A., Verheggen, B., Dommen, J., Duplissy, J., Prevot, A. S. H., Weingartner, E., Riipinen, I., Kulmala, M., Spracklen, D. V., Carslaw, K. S., and Baltensperger, U.: Evidence 
for the role of organics in aerosol particle formation under atmospheric conditions, P. Natl. Acad. Sci. USA, 107, 6646-6651, doi:10.1073/pnas.0911330107, 2010.

Müller, L., Reinnig, M.-C., Hayen, H., and Hoffmann, T.: Characterization of oligomeric compounds in secondary organic aerosol using liquid chromatography coupled to electrospray ionization Fourier transform ion cyclotron resonance mass spectrometry, Rapid Commun. Mass Sp., 23, 971-979, doi:10.1002/rcm.3957, 2009.

Ng, N. L., Canagaratna, M. R., Zhang, Q., Jimenez, J. L., Tian, J., Ulbrich, I. M., Kroll, J. H., Docherty, K. S., Chhabra, P. S., Bahreini, R., Murphy, S. M., Seinfeld, J. H., Hildebrandt, L., Donahue, N. M., DeCarlo, P. F., Lanz, V. A., Prévôt, A. S. H., Dinar, E., Rudich, Y., and Worsnop, D. R.: Organic aerosol components observed in Northern Hemispheric datasets from Aerosol Mass Spectrometry, Atmos. Chem. Phys., 10, 46254641, doi:10.5194/acp-10-4625-2010, 2010.

Novelli, A., Vereecken, L., Lelieveld, J., and Harder, H.: Direct observation of $\mathrm{OH}$ formation from stabilised Criegee intermediates, Phys. Chem. Chem. Phys., 16, 19941, doi:10.1039/C4CP02719A, 2014.

Pankow, J. F.: An absorption model of the gas/aerosol partitioning involved in the formation of secondary organic aerosol, Atmos. Environ., 28, 189-193, doi:10.1016/1352-2310(94)900949, 1994.

Peeters, J., Vereecken, L., and Fantechi, G.: The detailed mechanism of the $\mathrm{OH}$-initiated atmospheric oxidation of $\alpha$-pinene: a theoretical study, Phys. Chem. Chem. Phys., 3, 5489-5504, doi:10.1039/B106555F, 2001.

Pfaffenberger, L., Barmet, P., Slowik, J. G., Praplan, A. P., Dommen, J., Prévôt, A. S. H., and Baltensperger, U.: The link between organic aerosol mass loading and degree of oxygenation: an $\alpha$ pinene photooxidation study, Atmos. Chem. Phys., 13, 64936506, doi:10.5194/acp-13-6493-2013, 2013.

Praplan, A. P., Bianchi, F., Dommen, J., and Baltensperger, U.: Dimethylamine and ammonia measurements with ion chromatography during the CLOUD4 campaign, Atmos. Meas. Tech., 5, 2161-2167, doi:10.5194/amt-5-2161-2012, 2012.

Riccobono, F., Rondo, L., Sipilä, M., Barmet, P., Curtius, J., Dommen, J., Ehn, M., Ehrhart, S., Kulmala, M., Kürten, A., Mikkilä, J., Paasonen, P., Petäjä, T., Weingartner, E., and Baltensperger, U.: Contribution of sulfuric acid and oxidized organic compounds to particle formation and growth, Atmos. Chem. Phys., 12, 9427-9439, doi:10.5194/acp-12-9427-2012, 2012.

Riccobono, F., Schobesberger, S., Scott, C. E., Dommen, J., Ortega, I. K., Rondo, L., Almeida, J., Amorim, A., Bianchi, F., Breitenlechner, M., David, A., Downard, A., Dunne, E. M., Duplissy, J., Ehrhart, S., Flagan, R. C., Franchin, A., Hansel, A., Junninen, H., Kajos, M., Keskinen, H., Kupc, A., Kürten, A., Kvashin, A. N., Laaksonen, A., Lehtipalo, K., Makhmutov, V., Mathot, S., Nieminen, T., Onnela, A., Petäjä, T., Praplan, A. P., Santos, F. D., Schallhart, S., Seinfeld, J. H., Sipilä, M., Spracklen, D. V., Stozhkov, Y., Stratmann, F., Tomé, A., Tsagkogeorgas, G., Vaattovaara, P., Viisanen, Y., Vrtala, A., Wagner, P. E., Weingartner, E., Wex, H., Wimmer, D., Carslaw, K. S., Curtius, J., Donahue, N. M., Kirkby, J., Kulmala, M., Worsnop, D. R., and Baltensperger, U.: Oxidation products of biogenic emissions contribute to nucleation of atmospheric particles, Science, 344, 717-721, doi:10.1126/science.1243527, 2014.

Schnitzhofer, R., Metzger, A., Breitenlechner, M., Jud, W., Heinritzi, M., De Menezes, L.-P., Duplissy, J., Guida, R., Haider, S., Kirkby, J., Mathot, S., Minginette, P., Onnela, A., Walther, H., Wasem, A., Hansel, A., and the CLOUD Team: Characterisation of organic contaminants in the CLOUD chamber at CERN, Atmos. Meas. Tech., 7, 2159-2168, doi:10.5194/amt-7-2159-2014, 2014.

Schobesberger, S., Junninen, H., Bianchi, F., Lönn, G., Ehn, M., Lehtipalo, K., Dommen, J., Ehrhart, S., Ortega, I. K., Franchin, A., Nieminen, T., Riccobono, F., Hutterli, M., Duplissy, J., Almeida, J., Amorim, A., Breitenlechner, M., Downard, A. J., Dunne, E. M., Flagan, R. C., Kajos, M., Keskinen, H., Kirkby, J., Kupc, A., Kürten, A., Kurtén, T., Laaksonen, A., Mathot, S., Onnela, A., Praplan, A. P., Rondo, L., Santos, F. D., Schallhart, S., Schnitzhofer, R., Sipilä, M., Tomé, A., Tsagkogeorgas, G., Vehkamäki, H., Wimmer, D., Baltensperger, U., Carslaw, K. S., Curtius, J., Hansel, A., Petäjä, T., Kulmala, M., Donahue, N. M., and Worsnop, D. R.: Molecular understanding of atmospheric particle formation from sulfuric acid and large oxidized organic molecules, P. Natl. Acad. Sci. USA, 110, 17223-17228, doi:10.1073/pnas.1306973110, 2013.

Schobesberger, S., Franchin, A., Bianchi, F., Rondo, L., Duplissy, J., Kürten, A., Ortega, I. K., Metzger, A., Schnitzhofer, R., Almeida, J., Amorim, A., Dommen, J., Dunne, E. M., Ehn, M., Gagné, S., Ickes, L., Junninen, H., Hansel, A., Kerminen, V.-M., Kirkby, J., Kupc, A., Laaksonen, A., Lehtipalo, K., Mathot, S., Onnela, A., Petäjä, T., Riccobono, F., Santos, F. D., Sipilä, M., Tomé, A., Tsagkogeorgas, G., Viisanen, Y., Wagner, P. E., Wimmer, D., Curtius, J., Donahue, N. M., Baltensperger, U., Kulmala, M., and Worsnop, D. R.: On the composition of ammonia-sulfuric-acid ion clusters during aerosol particle formation, Atmos. Chem. Phys., 15, 55-78, doi:10.5194/acp-15-55-2015, 2015.

Seinfeld, J. H. and Pankow, J. F.: Organic atmospheric particulate material, Annu. Rev. Phys. Chem., 54, 121-140, doi:10.1146/annurev.physchem.54.011002.103756, 2003.

Shilling, J. E., Chen, Q., King, S. M., Rosenoern, T., Kroll, J. H., Worsnop, D. R., DeCarlo, P. F., Aiken, A. C., Sueper, D., Jimenez, J. L., and Martin, S. T.: Loading-dependent elemental composition of $\alpha$-pinene SOA particles, Atmos. Chem. Phys., 9, 771-782, doi:10.5194/acp-9-771-2009, 2009.

Sleno, L.: The use of mass defect in modern mass spectrometry, J. Mass Spectrom., 47, 226-236, doi:10.1002/jms.2953, 2012.

Szmigielski, R., Surratt, J. D., Gómez-González, Y., Van der Veken, P., Kourtchev, I., Vermeylen, R., Blockhuys, F., Jaoui, M., Kleindienst, T. E., Lewandowski, M., Offenberg, J. H., Edney, E. O., Seinfeld, J. H., Maenhaut, W., and Claeys, M.: 3-methyl-1,2,3-butanetricarboxylic acid: An atmospheric tracer for terpene secondary organic aerosol, Geophys. Res. Lett., 34, L24811, doi:10.1029/2007GL031338, 2007.

Taatjes, C. A., Shallcross, D. E., and Percival, C. J.: Research frontiers in the chemistry of Criegee intermediates and tropospheric ozonolysis, Phys. Chem. Chem. Phys., 16, 1704-1718, doi:10.1039/c3cp52842a, 2013.

Taira, M. and Kanda, Y.: Continuous generation system for lowconcentration gaseous nitrous acid, Anal. Chem., 62, 630-633, doi:10.1021/ac00205a018, 1990. 
Tolocka, M. P., Jang, M., Ginter, J. M., Cox, F. J., Kamens, R. M., and Johnston, M. V.: Formation of oligomers in secondary organic aerosol, Environ. Sci. Technol., 38, 1428-1434, doi:10.1021/es035030r, 2004.

Vereecken, L. and Peeters, J.: Nontraditional (per)oxy ringclosure paths in the atmospheric oxidation of isoprene and monoterpenes, J. Phys. Chem. A, 108, 5197-5204, doi:10.1021/jp049219g, 2004.
Vereecken, L., Harder, H., and Novelli, A.: The reaction of Criegee intermediates with $\mathrm{NO}, \mathrm{RO}_{2}$, and $\mathrm{SO}_{2}$, and their fate in the atmosphere, Phys. Chem. Chem. Phys., 14, 14682, doi:10.1039/c2cp42300f, 2012.

Winkler, P. M., Ortega, J., Karl, T., Cappellin, L., Friedli, H. R., Barsanti, K., McMurry, P. H., and Smith, J. N.: Identification of the biogenic compounds responsible for sizedependent nanoparticle growth, Geophys. Res. Lett., 39, L20815, doi:10.1029/2012GL053253, 2012. 